\title{
The genus Aphidura (Hemiptera,Aphididae) in the collection of the Muséum national d'Histoire naturelle of Paris, with six new species
}

\author{
Juan-Manuel Nieto Nafría ${ }^{1, \dagger}$, Milagros-Pilar Mier Durante ${ }^{1, \ddagger}$, Georges Remaudière \\ I Departamento de Biodiversidad y Gestión Ambiental, Universidad de León, 24071 León, Spain 2 Départe- \\ ment de Systématique et Évolution, Muséum national d'Histoire naturelle, 45 rue Buffon, 75005 Paris, France \\ † urn:lsid:zoobank.org:author:81F0702F-538F-4AB4-92A9-74580A562221 \\ ‡ urn:lsid:zoobank.org:author:5201A45A-D509-423F-8B7B-D2F786716FBE \\ § urn:lsid:zoobank.org:author:D3783C87-9BBD-4081-B858-AC12996B37AO
}

Corresponding author: Juan-Manuel Nieto Nafría (jmnien@unileon.es)

Academic editor: Roger Blackman | Received 29 May 2013 | Accepted 18 July 2013 | Published 23 July 2013

urn:lsid:zoobank.org:pub:CE9B6D0B-7E96-4B92-906B-6CC5284440C3

Citation: Nieto Nafría JM, Mier Durante MP, Remaudière G (2013) The genus Aphidura (Hemiptera, Aphididae) in the collection of the Muséum national d'Histoire naturelle of Paris, with six new species. ZooKeys 318: 1-33. doi: 10.3897/ zookeys.318.5693

\begin{abstract}
Specimens were studied of 65 samples of the genus Aphidura (Aphididae, Aphidinae, Macrosiphini) from the collection of the Muséum national d'Histoire naturelle (Paris). The possible synonymies of three pairs of species are discussed. New aphid host plant relationships are reported for A. bozhkoae, A. delmasi, $A$. ornata, $A$. pannonica and $A$. picta; this last species is recorded for first time from Afghanistan. The record of $A$. pujoli from Pakistan is refuted. The fundatrices, oviparous females and males of $A$. delmasi are described. Six new species are established: A. gallica sp. n. and $A$. amphorosiphon sp. n. from specimens caught on species of Silene (Caryophyllaceae) from France and Iran, respectively, A. pakistanensis sp. n., A. graeca sp. n. and A. urmiensis sp. n. from specimens caught on species of Dianthus, Gypsophila and Spergula (Caryophyllaceae) from Pakistan, Greece and Iran, respectively, and A. iranensis sp. n. from specimens caught on Prunus sp. from Iran. Modifications are made to the keys by Blackman and Eastop to aphids living on Dianthus, Gypsophyla, Silene, Spergula and Prinsepia and Prunus (Rosaceae). An identification key to apterous viviparous females of species of Aphidura is also provided.
\end{abstract}

\section{Keywords}

New taxa, descriptions, synonymies, key of species, host plants, distributions

Copyright Juan-Manuel Nieto Nafría et al. This is an open access article distributed under the terms of the Creative Commons Attribution License 3.0 (CC-BY), which permits unrestricted use, distribution, and reproduction in any medium, provided the original author and source are credited. 


\section{Introduction}

In the early 1980s G. Remaudière and D. Hille Ris Lambers studied some samples of Aphidura (Hemiptera, Aphididae, Aphidinae, Macrosiphini) belonging to the Remaudière collection, which was at that time at the Institut Pasteur in Paris, but later moved to the Muséum national d'Histoire naturelle. They made preliminary works to describe several new species of this genus, but the work was interrupted and a manuscript draft was never prepared due to the illness and death in April 1984 of Hille Ris Lambers. Some of the slides studied by Hille Ris Lambers were sent with the rest of his collection to the British Museum (Natural History), currently the Natural History Museum, in London. Some years later Remaudière did establish one new species in this genus (Remaudière 1989) but this was from specimens that had not been part of his studies with Hille Ris Lambers.

All those samples, together with the rest of the specimens of Aphidura of the above-mentioned collection, have now been studied, and the results are presented in this paper.

The genus Aphidura was morphologically well defined by Hille Ris Lambers (1956), and the type species, $A$. ornata Hille Ris Lambers, is also well defined, so no doubt exists about the correct taxonomic position of the species included within it. Apterous viviparous aphids can be identified as Aphidura, in addition to the characteristics of the tribe Macrosiphini, by the presence of a pair of mesosternal mammariform processes (in Hille Ris Lambers's words: "Distinct, conspicuously pigmented or pale, rough mammiform processi present on anterior part of mesosternum in apterae and larvae»), together with a triangular or tongue-shaped cauda and reniform spiracular apertures centred in the respective sclerites.

Similar mesosternal processes are also present in several species of Brachycaudus van der Goot, 1913, mainly belonging to subgenus Acaudus van der Goot, 1913, and in the sole species of Zinia, Z. veronicae Shaposhnikov, 1950. These species of Brachycaudus have a helmet-shaped cauda and wide, rounded spiracular apertures, and $Z$. veronicae has a rounded cauda, reniform spiracular apertures that are placed in the posterior half of the spiracular sclerites and, in addition the dorsal cuticle is densely spinulose (Hille Ris Lambers 1956, Shaposhnikov 1950, Andreev 2004).

Aphidura currently includes 16 to 18 species and 1 subspecies (Blackman and Eastop 2006, Kadyrbekov 2013): A. acanthophylli Remaudière, 1989, A. alatavica Kadyrbekov, 2013, A. bozhkoae (Narzikulov, 1958) (type species of Cerasomyzus Narzikulov, 1958, which was established as subgenus of Myzus Passerini), A. delmasi Remaudière and Leclant, 1965, A. gypsophilae Mamontova-Solukha, 1963, A. massagetica Kadyrbekov, 2013, A. melandrii Kadyrbekov, 2013, A. mordvilkoi Shaposhnikov, 1984 (with its possible synonym $A$. prinsepiae Pashchenko, 1988), A. naimanica Kadyrbekov, 2013, A. nomadica Kadyrbekov, 2013, A. ornata Hille Ris Lambers, 1956, A. ornatella Narzikulov \& Winkler, 1960 (with its possible synonym $A$. bharatia David, Sekhon \& Bindra, 1970), A. pannonica Szelegiewicz, 1967 (with subspecies $A$. pannonica cretacea Mamontova-Solukha, 1968), A. picta Hille Ris Lambers, 1956 (with its possible 
synonym $A$. mingens Pintera, 1970), A. pujoli (Gómez-Menor Ortega, 1950) and $A$. togaica Kadyrbekov, 2013.

Two species of Aphidura live on Rosaceae species and other species live on Caryophyllaceae species, mainly belonging to genus Silene. A. pujoli is monoecious holocyclic on Caryophyllaceae; it is possible that the life cycle of other species of Aphidura is also monoecious holocyclic, though it is also possible that some species host-alternate between species of Rosaceae and Caryophyllaceae (Blackman and Eastop 2006, Holman 2009, Kadyrbekov 2013).

The genus exhibits a Mediterranean-Pontian-Turanian distribution with extensions to neighbouring areas and exceptionally - A. mordvilkoi - to the Russian Far East. The current known distribution of each species is shown in the species identification key at the end of this paper, $A$. picta being the species with the widest distribution (Blackman and Eastop 2006, Holman 2009, Nieto Nafría et al. 2012, Kadyrbekov 2013).

\section{Material and methods}

Aphidura specimens of the aphid collection of the Muséum national d'Histoire naturelle of Paris, mounted in microscopic slides, belonging to 65 samples (Table 1) have been studied.

Aphids were identified, or their previous identifications were checked, by reference to the original descriptions (Hille Ris Lambers 1956, Gómez-Menor Ortega 1950, Narzikulov 1958, Narzikulov and Winkler 1960, Mamontova-Solukha 1963, Remaudière and Leclant 1965, Szelegiewicz 1967, Mamontova-Sholukha 1968, David et al. 1970, Pintera 1970, Shaposhnikov 1984, Pashchenko 1988, Remaudière 1989, Kadyrbekov 2013) and other informative works (Eastop and Blackman 2005, Blackman and Eastop 1994, 2006).

Morphological measurements were made according to Nieto Nafría and Mier Durante (1998). In the descriptions and keys, measurements are lengths except when indi-

Table I. Studied samples.

\begin{tabular}{|c|c|c|c|c|c|}
\hline $\begin{array}{l}\text { Aphidura species } \\
\text { Host plant }\end{array}$ & Country & Locality & Date & Coll. & Sample \\
\hline \multicolumn{6}{|l|}{ A. acanthophylli } \\
\hline Acanthophyllum sp. & Iran & $\begin{array}{c}\text { Sharh-e Babak [NW } 50 \mathrm{~km}] \\
\text { (Kerman) }\end{array}$ & 4-IX-1972 & R. & i3749 \\
\hline \multicolumn{6}{|c|}{ A. amphorosiphon sp. n. } \\
\hline Dianthus sp. & Iran & without locality & sans date & D. & $\mathrm{i} 1440$ \\
\hline Silene sp. & Iran & $\begin{array}{c}\text { Kuh-e Dinar (Kohgiluyed and } \\
\text { Boyer-Ahmad) }\end{array}$ & 14-IX-1955 & R. & i1118a \\
\hline Caryophyllaceae & Iran & $\begin{array}{c}\text { Chalus [N } 40 \mathrm{~km} \text { Amol road] } \\
\text { (Mazenderan) }\end{array}$ & $3-V-1963$ & R. & i2417 \\
\hline \multicolumn{6}{|l|}{ A. bozbkoae } \\
\hline Prunus spinosa & Iran & Karadj (Alborz) & $8-V-1955$ & R. & i196 \\
\hline Prunus?prostrata & Iran & $\begin{array}{c}\text { Bojnurd [E } 10 \mathrm{~km}] \text { (North } \\
\text { Khorasan) }\end{array}$ & $21-V-1966$ & $\mathrm{R}$. & i2961 \\
\hline
\end{tabular}




\begin{tabular}{|c|c|c|c|c|c|}
\hline $\begin{array}{l}\text { Aphidura species } \\
\text { Host plant }\end{array}$ & Country & Locality & Date & Coll. & Sample \\
\hline Prunus ?prostrata & Iran & $\begin{array}{c}\text { Kuh-e Choret [90 km. Bojnurd] } \\
\text { (North Khorasan) }\end{array}$ & $25-V-1966$ & R. & i3028 \\
\hline \multirow[t]{2}{*}{ Prunus sp. } & Iran & $?$ & $?$ & $?$ & $\mathrm{i} 4347$ \\
\hline & Iran & Shiraz (Fars) & ?-V-1974 & C. & $\mathrm{i} 4092$ \\
\hline \multicolumn{6}{|l|}{ A. delmasi } \\
\hline Silene italica & France & Gémenos (Bouches-du-Rhône) & 13-VI-1967 & R. & 6455 \\
\hline Silene italica & France & Lantosque (Alpes-Maritimes) & $24-X-1968$ & $\mathrm{R}$. & 7591 \\
\hline Silene italica & France & $\begin{array}{l}\text { Saint-Guilhem-le-Désert } \\
\text { (Hérault) }\end{array}$ & 17-IV-1966 & $\mathrm{R}$. & 5751 \\
\hline Silene italica & France & $\begin{array}{l}\text { Saint-Guilhem-le-Désert } \\
\text { (Hérault) }\end{array}$ & 21-VII-1966 & $\mathrm{L}$. & 5752 \\
\hline Silene italica & France & $\begin{array}{l}\text { Saint-Guilhem-le-Désert } \\
\text { (Hérault) }\end{array}$ & 30-IX-1966 & $\mathrm{L}$. & 5753 \\
\hline Silene italica & France & Pont du Gard (Gard) & 19-III-1969 & R.\&L. & 7728 \\
\hline Silene italica & France & Utelle (Alpes-Maritimes) & $11-V-1969$ & R.\&L. & 7876 \\
\hline Silene italia & France & Utelle (Alpes-Maritimes) & 13-VI-1988 & R. & 15798 \\
\hline Silene ?viscosa & France & Finistret (Pyrénées Orientales) & 9-VI-1983 & $\mathrm{R}$. & 14459 \\
\hline Silene sp. & Greece & Lagadie [East] (Akadia) & 3-VII-1964 & R. & 03087 \\
\hline Silene sp. & France & Lantosque (Alpes-Maritimes) & 28-II-1970 & $\mathrm{R}$. & 9258 \\
\hline Silene sp. & France & La-Garde-Freinet (Var) & 26-III-1970 & $\mathrm{R}$. & 9357 \\
\hline Silene sp. & France & $\begin{array}{l}\text { Saint-Jean la-Rivière } \\
\text { (Alpes-Maritimes) }\end{array}$ & 16-IX-1969 & R. & 8690 \\
\hline vagrant & France & Utelle (Alpes-Maritimes) & 7-XI-1989 & $\mathrm{R}$. & $16079 \mathrm{~b}$ \\
\hline \multicolumn{6}{|l|}{ A. gallica sp. n. } \\
\hline Silene gallica & France & $\begin{array}{c}\text { Banyuls-sur-Mer } \\
\text { (Pyrénées-Orientales) }\end{array}$ & 11-VII-1957 & $\mathrm{R}$. & 4241 \\
\hline Silene paradoxa & France & Defilé de l'Inzecca (Haute-Corse) & 4-VI-1979 & L. & 17925 \\
\hline \multicolumn{6}{|l|}{ A. graeca sp. n. } \\
\hline Gypsophila sp. & Greece & Veria [to Kastania] (Imanthia) & 18-VI-1964 & $\mathrm{R}$. & 03026 \\
\hline \multicolumn{6}{|l|}{ A. gypsophilae } \\
\hline Gypsophila paniculata & Slovakia & Chotín (Nitra) & 25-VI-1984 & $\mathrm{H}$. & 015379 \\
\hline \multicolumn{6}{|l|}{ A. iranensis sp. $\mathrm{n}}$. \\
\hline Prunus sp. & Iran & $\begin{array}{c}\text { Khoy [N } 30 \mathrm{~km}] \text { (West } \\
\text { Azerbaijan) }\end{array}$ & 7-VIII-1955 & R. & i982 \\
\hline \multicolumn{6}{|l|}{ A. mordvilkoi } \\
\hline Princepia sinensis & Russia & ? (Prymorsky Krai) & $20-V I-1967$ & Sh. & 016559 \\
\hline Princepia sinensis & Russia & ? (Prymorsky Krai) & 5-VI-1980 & Pa. & 014789 \\
\hline \multicolumn{6}{|l|}{ A. ornata } \\
\hline Silene inaperta & France & $\begin{array}{c}\text { Ste Catherine de Vars (Hautes- } \\
\text { Alpes) }\end{array}$ & 1-VII-1990 & R.\&M.V. & 16454 \\
\hline Silene italica & France & Avène (Hérault) & $1-V-1967$ & $\mathrm{~L}$. & 18054 \\
\hline Silene nutans & Switzerland & Cassarate (Ticino) & $25-V-1950$ & H.R.L. & 02946 \\
\hline Silene nutans & Switzerland & Cassarate (Ticino) & $25-\mathrm{V}-1950$ & H.R.L. & 016758 \\
\hline Silene saxifraga & France & $\begin{array}{l}\text { La-Roche-de-Rame [S] } \\
\text { (Hautes-Alpes) }\end{array}$ & 22-VI-1969 & R.\&L. & 8010 \\
\hline \multicolumn{6}{|l|}{ A. ornatella } \\
\hline Silene sp. & Pakistan & Matiltan (Khyber Pakhtunkhwa) & 14-VIII-1991 & N-E. & 014109 \\
\hline trap & Pakistan & Kalam Khyber Pakhtunkhwa & ?-?-1987 & N-E. & \\
\hline trap & Pakistan & Matiltan (Khyber Pakhtunkhwa) & 23-VII-1987 & N-E. & \\
\hline
\end{tabular}




\begin{tabular}{|c|c|c|c|c|c|}
\hline $\begin{array}{l}\text { Aphidura species } \\
\text { Host plant }\end{array}$ & Country & Locality & Date & Coll. & Sample \\
\hline trap & Pakistan & $\begin{array}{l}\text { Matiltan (Khyber } \\
\text { Pakhtunkhwa) }\end{array}$ & 30-VII-1987 & N-E. & \\
\hline \multicolumn{6}{|l|}{ A. pakistanensis sp. $\mathrm{n}$. } \\
\hline Dianthus sp.- & Pakistan & Kalam (Khyber Pakhtunkhwa) & 17-VIII-1981 & N-E. & 014072 \\
\hline \multicolumn{6}{|l|}{ A.pannonica } \\
\hline Gypsophila paniculata & Hungary & Ágasegyháza (Bács-Kiskun) & 10-VI-1968 & Sz. & 014156 \\
\hline Silene otites & Hungary & Budapest [Sas-hegy] (Pest) & 21-VI-1964 & Sz. & 014156 \\
\hline Silene otites & Slovakia & Chotín (Nitra) & 25-VI-1984 & $\mathrm{H}$. & 015380 \\
\hline Silene otites & Slovakia & Somotor (Košice) & 27-VI-1962 & Pi. & 010615 \\
\hline \multicolumn{6}{|l|}{ A. picta } \\
\hline Dianthus barbatus & Pakistan & Quetta (Baluchistan) & $14-\mathrm{V}-1991$ & N-E. & 013878 \\
\hline Dianthus crinutus & Pakistan & Skardu (Gilgit-Baltistan) & 2-VII-1991 & N-E. & 013965 \\
\hline Dianthus ?barbatus & Iran & Isfahan (Isfahan) & 25-IV-1978 & R. & $\mathrm{i} 4222$ \\
\hline Dianthus sp. & Afghanistan & Kabul (Kabul) & 26-VI-1972 & & 04565 \\
\hline Dianthus sp. & Iran & Karadj (Alborz) & ?-XI-1948 & D. & i81a \\
\hline Dianthus sp. [cult.] & Turkey & Ankara (Ankara) & $8-\mathrm{X}-1950$ & T. & 011930 \\
\hline Silene conoida & Iran & Laleeh zar (Kerman) & 26-VI-1955 & $\mathrm{R}$. & $\mathrm{i} 648$ \\
\hline Silene fruticosa & Italy & Castelmola (Messina) & 9-VI-1979 & B. & 012841 \\
\hline Silene glauca & Spain & Callosa de Ensiarrá (Alicante) & $29-V-985$ & G.F. & 012841 \\
\hline Silene italica & France & Col Turini (Alpes-Maritimes) & $15-X-1969$ & R. & 8672 \\
\hline Silene italica & France & Lantosque (Alpes-Maritimes) & $24-X-1968$ & $\mathrm{R}$. & 7592 \\
\hline Silene sp. & Iran & Karadj (Alborz) & $19-\mathrm{V}-1955$ & $\mathrm{R}$. & $\mathrm{i} 282 \mathrm{c}$ \\
\hline \multicolumn{6}{|l|}{ A.pujoli } \\
\hline Dianthus caryophyllus & France & $\begin{array}{l}\text { Defilé de l'Inzecca (Haute- } \\
\text { Corse) }\end{array}$ & 4-VI-1970 & $\mathrm{L}$. & 18055 \\
\hline Dianthus caryophyllus & France & $\begin{array}{l}\text { Defilé de l'Inzecca (Haute- } \\
\text { Corse) }\end{array}$ & $4-\mathrm{VI}-1970$ & L. & 18056 \\
\hline Dianthus caryophyllus & Italy & $\begin{array}{c}\text { Ercolano [previously Resina] } \\
\text { (Napoli) }\end{array}$ & 17-VIII-1936 & Ro. & 02947 \\
\hline Dianthus sp. & Spain & Arenas de Cabrales (Asturias) & 7-VI-1981 & R.\&N.N. & 012841 \\
\hline Dianthus sp. & France & $?$ & $?$ & $?$ & 5670 \\
\hline trap & France & Montpellier (Hérault) & 16-VII-1996 & $?$ & 17749 \\
\hline trap & France & Valence (Charente) & 1-VII-1996 & $?$ & 17755 \\
\hline \multicolumn{6}{|l|}{ A. urmiensis sp. $\mathrm{n}$. } \\
\hline Spergularia marina & Iran & $\begin{array}{l}\text { Charimboulaki, Lac Urmia } \\
\text { (West Azerbaijan) }\end{array}$ & 9-VIII-955 & $\mathrm{R}$. & i1004 \\
\hline Spergularia marina & Iran & $\begin{array}{l}\text { Shahi island, Lac Urmia (East } \\
\text { Azerbaijan) }\end{array}$ & 5-VIII-1955 & R. & i962 \\
\hline
\end{tabular}

\section{NOTES:}

In the "Locality" column, supplementary information and upper administrative unit (such as county, department, province, regional unit, etc.) are respectively given in square brackets and in parentheses. In the "Coll" column the names of collectors have been abbreviated as follows: B., Barbagallo (S.); C., Chodjaï (M.); D., Davatchi (A.); G.F., González Funes (M.P.); H.R.L, Hille Ris Lambers (D.); H., Holman (J.); L., Leclant (F.); M.V. Muñoz Viveros (A.L.); N.N., Nieto Nafría (J.M.); N-E , Naumann-Etienne (K.); Pa., Pashchenko (N.S.); P., Pintera (A.); R., Remaudière (G.); Ro., Roberti (D.) Sh., Shaposhnikov (G.C.); Sz., Szelegiewicz (H.); and T., Tuatay (N.).

The numbers in the "Sample" column are the numbers of the Remaudière samples. 
cated otherwise as width or diameter. A Leica DC digital 96 camera with IM 1000 version 1.10 software was used for the photomicrographs, which have been taken and mounted by L. M. Fernández Blanco.

In the modifications to the identification keys by Blackman and Eastop (1994, 2006) that are included in the discussion of each species, the terms that they use (for example 'hair' instead of 'seta' and 'clavate' instead of 'swollen') have been retained so that they can be easily understood and used by those accustomed to them.

\section{Results and discussion}

\section{Generic characters}

Apterous viviparous aphids can be identified as Aphidura by the presence of a pair of mesosternal mammariform processes, as mentioned above, and also by the following characters: (1) frons w-shaped with rugose or scabrous lateral tubercles not much higher than the broad median tubercle; (2) cephalic dorsum not ornamented or with spinules, which may be more-or-less scattered or in groups; (3) clypeus and mandibular and maxillar lamina more-or-less pigmented like cephalic dorsum and rostrum; (4) antennae not longer than body length; (5) secondary sensoria absent; (6) antennal segment I and II scabrous or rugose, segment III with scattered scales, and IV-VI more-or-less imbricated; (7) rostrum extending backward beyond middle coxae or reaching hind coxae; (8) ultimate rostral segment triangular with straight margins, usually darker than the previous segments; (9) legs with coxae and trochanters pale, femora entirely pale or with a darker distal part; tibiae pale in general with a distal portion smoky, exceptionally entirely pale, and tarsi brown; (10) first segment of tarsi with 2-4 setae; (11) abdominal spiracular apertures reniform, placed in the middle of small spiracular sclerites; (12) intersegmental sclerites well defined and usually pigmented, and embodied in the segmental sclerites if these are present; (13) thorax and abdomen often with a dorsal pattern of sclerotisation that is very variable between species, and can also vary within them (see below terminological usage); (14) siphunculi usually with a distinct preapical incision and flange, but variable in shape (see below for details and terminological usage); (15) cauda triangular to tongue-shaped; (16) spinules present, more-or-less conspicuously and densely, on mesosternal mammariform processes, postsiphuncular sclerites, spiracular sclerites 7, and abdominal terga 7 and 8; (17) antennal and dorsal setae short or very short, with blunt, frayed or (rarely) incrassated apex; (18) dorsal setae not placed on tubercles, except sometimes in $A$. acanthophylli; (19) ventral setae longer than respective dorsal and pointed; and (20) setae on dorsal faces of femora and on proximal parts of tibiae with blunt or frayed apex, other setae on legs pointed.

The alate viviparous females have no mesosternal mammariform processes, and differ from apterae by having: (a) longer and more pigmented antennae, (b) round, double-rimmed secondary sensoria scattered along the ventral face of antennal segment III, and rarely on segment IV, (c) pigmentation of legs more extensive and darker; (d) dor- 
sal abdomen often with more sclerotisation than in apterae, but again this varies greatly both between and within species; (e) spinules also present in the marginal sclerites.

Regarding the thoracic and abdominal dorsal sclerotisation, the term "spinopleural patch" is utilized here for a continuous sclerotisation of spinal and marginal areas of two or more segments (Figs 2B, D, 4A, 6A), and the term "discal plate" is utilized for the continuous and extensive sclerotisation of spinal, pleural and marginal areas of three or more segments (Figs 1A, C, 2A, C).

The siphunculi of Aphidura species are variable in shape: (a) cylindrical, subcylindrical (delicately tapering to the apex) or conspicuously tapering from base to apex, straight or curved outward (Figs 1D, 2A, 4B, 6A); (b) slightly swollen — «cylindrical with very tapering apex, below their middle very little attenuated, so that they might be considered as very slightly clavate» (Hille Ris Lambers 1956) - , having the maximal width of the distal half less than 1.2 times the minimal width of the stem (Figs 2D, 3A, 5B, 6A); (c) markedly swollen, with large base, cylindrical stem and a conspicuously swollen distal portion, the width of which is conspicuously greater (at least 1.2 times) than the minimal stem width (Figs 1A, 4D, 5C, 6B).

\section{Synonymies in Aphidura}

Possible synonymies of three pairs of Aphidura species are discussed: A. bharatia and A. ornatella, $A$. mingens and $A$. picta, and finally $A$. prinsepiae and $A$. mordvilkoi.

Eastop and Blackman (2005) established that $A$. bharatia is a synonym of the older name A. ornatella. Both species are considered valid by Kadyrbekov (2013) because he found differences between aphids identified as bharatia and others identified as ornatella, although he does not refer to Eastop and Blackman's paper. In our opinion these differences could be enough to keep the validity of both species, but they can also be an expression of intraspecific variability, which would present a cline North to South; Kadyrbekov himself shows differences between ornatella populations from Kazakhstan and Tajikistan.

Characters of studied apterous and alate vivipara (Figs 1A, B; Table 2 for six alatae from Pakistan; only one alate of this species was previously known [Kadyrbekov 2013]), overlap characters mentioned by Kadyrbekov for southern (from India and Pakistan) and northern (from Kazakhstan and Tajikistan) populations. In conclusion, we consider it is preferable to keep the synonymy.

The species pair Aphidura mingens and A. picta provides a similar situation: they are considered synonymous names by Eastop and Blackman (2005) and valid names by Kadyrbekov (2013), who found differences in the siphunculi shape (slightly swollen in picta specimens and subcylindrical, more or less tapering and curved outwards in mingens specimens) and in several quantitative characters. The original description of $A$. picta is quite unsatisfactory because it is based on one specimen "untypical of the species as a whole» (Eastop and Blackman, op. cit), which «might be a fundatrix of that species [A. ornata]» (Hille Ris Lambers 1956), and the species is so variable in sclerotisation, pigmentation, siphuncular shape and setal length (Fig. 1C). 


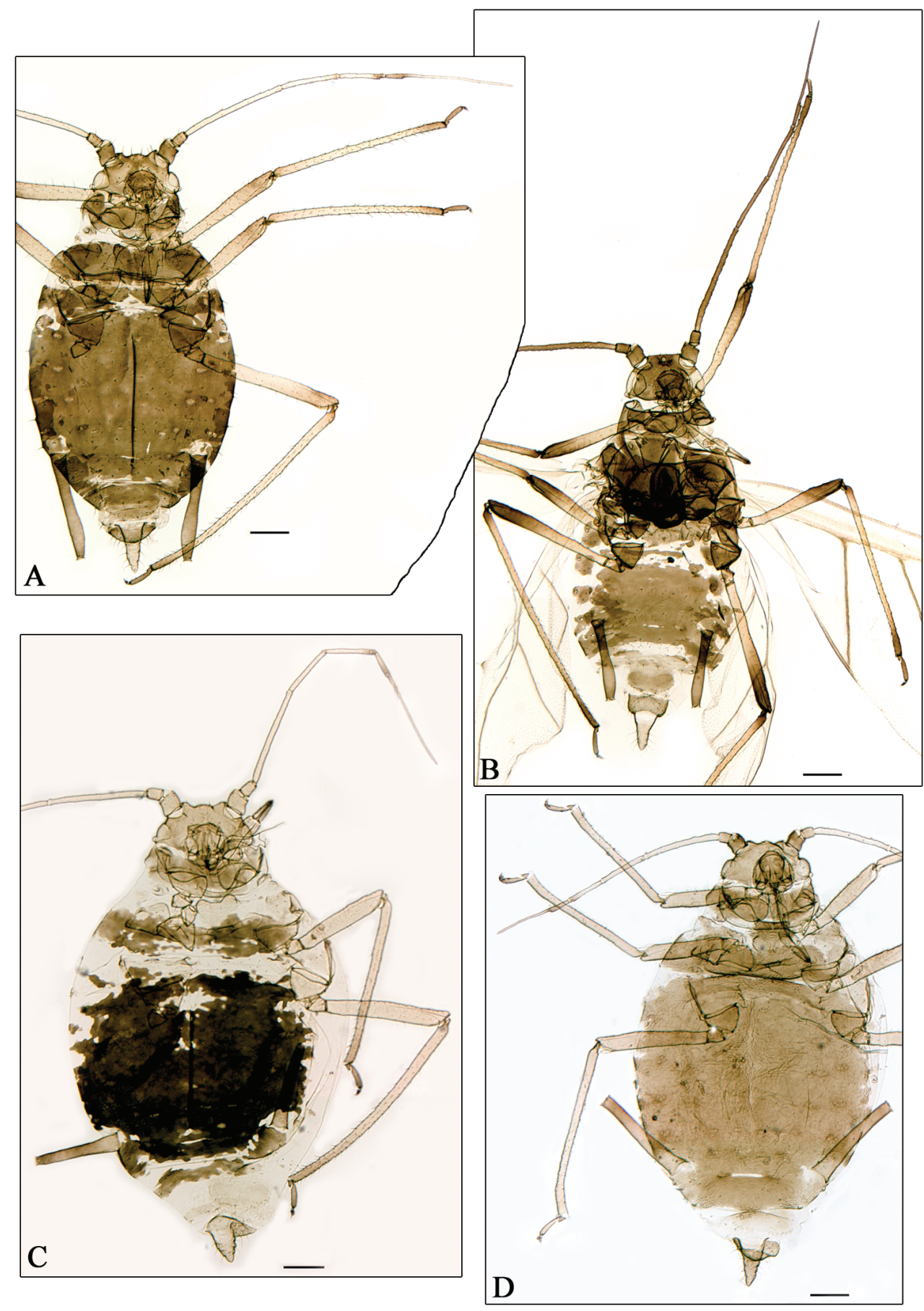

Figure I. A-B Aphidura ornatella C A. picta D A. mordvilkoi A, C-D apterous viviparous female B alate viviparous female. Scale bars $0.2 \mathrm{~mm}$. 
Table 2. Metric and meristic features of Aphidura ornatella, and A. delmasi; n, number of measured specimens.

\begin{tabular}{|c|c|c|c|c|}
\hline & A. ornatella & A. delmasi & A. delmasi & A. delmasi \\
\hline & Al. viv. femal. & Fundatrices & Ovip. femal. & Males \\
\hline & $n=6$ & $n=4$ & $n=4$ & $\mathrm{n}=4$ \\
\hline Body [mm] & $1.637-2.100$ & $1.700-2.200$ & $1.625-1.775$ & $1.175-1.425$ \\
\hline Antenna [mm] & $1.565-2.060$ & $1.115-1.500$ & $1.660-1.825$ & $1.555-1.725$ \\
\hline Antenna / Body [times] & $0.96-1.11$ & $0.65-0.68$ & $1.01-1.12$ & $1.20-1.44$ \\
\hline Ant. segm. III [mm] & $0.40-0.58$ & 0.28 & 0.44 & $0.40-0.41$ \\
\hline Ant. segm. IV [mm] & $0.24-0.36$ & $0.16-0.24$ & $0.29-0.37$ & $0.27-0.33$ \\
\hline Ant. segm. V [mm] & $0.21-0.29$ & $0.15-0.23$ & $0.25-0.26$ & $0.21-0.25$ \\
\hline Ant. segm. VI base $[\mathrm{mm}]$ & $0.11-0.13$ & $0.11-0.13$ & $0.12-0.13$ & $0.11-0.12$ \\
\hline Ant. segm. VI processus terminalis [mm] & $0.50-0.67$ & $0.24-0.29$ & $0.44-0.48$ & $0.40-0.50$ \\
\hline $\begin{array}{l}\text { Ant. segm. VI processus terminalis/ Ant. segm. } \\
\text { III [times] }\end{array}$ & $1.09-1.24$ & $0.62-0.93$ & $1.1-1.20$ & $1.00-1.22$ \\
\hline Ant. segm. VI processus terminalis/ base [times] & $4.62-5.36$ & $1.96-2.48$ & $3.62-4.04$ & $3.48-4.30$ \\
\hline $\begin{array}{l}\text { Secondary sensoria, Ant. segm. III [number] } \\
\text { ne }\end{array}$ & $21-28$ & 0 & 0 & 0 \\
\hline Ultimate rostral segm. [mm] & $0.12-0.15$ & $0.13-0.15$ & $0.15-0.17$ & 0.14 \\
\hline Ultimate rostral segm. / its basal width [times] & $2.09-3.00$ & $2.00-2.25$ & $2.50-2.82$ & $2.00-2.80$ \\
\hline $\begin{array}{l}\text { Ultimate rostral segm. / Ant. segm. VI base } \\
\text { [times] }\end{array}$ & $1.08-1.16$ & $1.12-1.29$ & $1.15-1.35$ & $1.17-1.33$ \\
\hline Hind tarsus, 2nd segm. [mm] & $0.11-0.14$ & $0.09-0.10$ & $0.01-0.11$ & $0.08-0.09$ \\
\hline $\begin{array}{l}\text { Hind tarsus, 2nd segm. / Ultimate rostral segm. } \\
\text { [times] }\end{array}$ & $0.93-1.04$ & $0.67-0.70$ & $0.65-0.71$ & $0.57-0.67$ \\
\hline Abdominal Marginal papillae [number] & 0 & 0 & 0 & 0 \\
\hline Siphunculus [mm] & $0.38-0.42$ & $0.23-0.31$ & $0.29-0.32$ & $24-0.26$ \\
\hline Siphunculus / Body [times] & $0.19-0.23$ & $0.13-0.15$ & $0.17-0.20$ & $0.17-0.21$ \\
\hline Siphunculus / Ant. segm. III [times] & $0.68-0.95$ & $0.71-0.83$ & $0.72-0.80$ & $0.59-0.66$ \\
\hline Siphunculus / its basal width [times] & $5.07-6.25$ & $3.22-4.43$ & $4.41-4.75$ & $4.00-4.64$ \\
\hline Siphuncular widths, maximal / basal [times] & $0.80-1.25$ & $0.72-0.86$ & $0.83-0.92$ & $0.80-0.91$ \\
\hline Siphuncular widths, maximal / minimal [times] & $1.47-2.33$ & 1 & 1 & 1 \\
\hline Cauda $[\mathrm{mm}]$ & $0.13-0.19$ & $0.15-0.22$ & $0.18-0.19$ & $0.10-0.15$ \\
\hline Cauda / Siphunculus [times] & $0.34-0.51$ & $0.67-0.74$ & $0.58-0.63$ & $0.37-0.60$ \\
\hline Cauda / its basal width [times] & $1.05-1.41$ & $1.20-1.43$ & $1.29-1.42$ & $0.68-1.33$ \\
\hline \multicolumn{5}{|l|}{ Setae on ... } \\
\hline$\ldots$ Frons $[\mu \mathrm{m}]$ & $21-28$ & $35-50$ & $45-55$ & $35-45$ \\
\hline ... Frons / b. d. Ant. segm. III [times] & $1.1-1.8$ & $1.6-2.5$ & $2.0-2.8$ & $1.8-2.3$ \\
\hline ... Ant. segm. III $[\mu \mathrm{m}]$ & $12-20$ & $17-23$ & $22-25$ & $17-23$ \\
\hline ... Ant. segm III / b. d. Ant. segm. III [times] & $0.7-1.1$ & $0.9-1.0$ & $1.0-1.3$ & $0.9-1.3$ \\
\hline ... Ultimate rostral segm. [number] & $14-17$ & $5-8$ & $8-12$ & $9-12$ \\
\hline$\ldots$ Abdominal segm. $8[\mu \mathrm{m}]$ & $25-35$ & $35-45$ & $45-50$ & $38-40$ \\
\hline $\begin{array}{l}\text {... Abdominal segm. } 8 \text { / b. d. Ant. segm. III } \\
\text { [times] }\end{array}$ & $1.3-2.0$ & $1.6-2.3$ & $2.0-2.4$ & $2.0-2.1$ \\
\hline ... Abdominal segm. 8 [number] & $4-5$ & $4-7$ & $4-5$ & $3-6$ \\
\hline ... Genital plate, discal [number] & $2-4$ & $2-8$ & $7-10$ & - \\
\hline ... Genital plate, marginal [number] & $10-16$ & $12-13$ & $17-21$ & - \\
\hline ... Cauda [number] & $6-8$ & $6-8$ & $8-10$ & 69 \\
\hline
\end{tabular}

NOTE. Used abbreviations: Al., Alate; Ant., Antennal; b. d., basal diameter; femal., females; Ovip., Oviparous; segm., segment; viv., viviparous. 

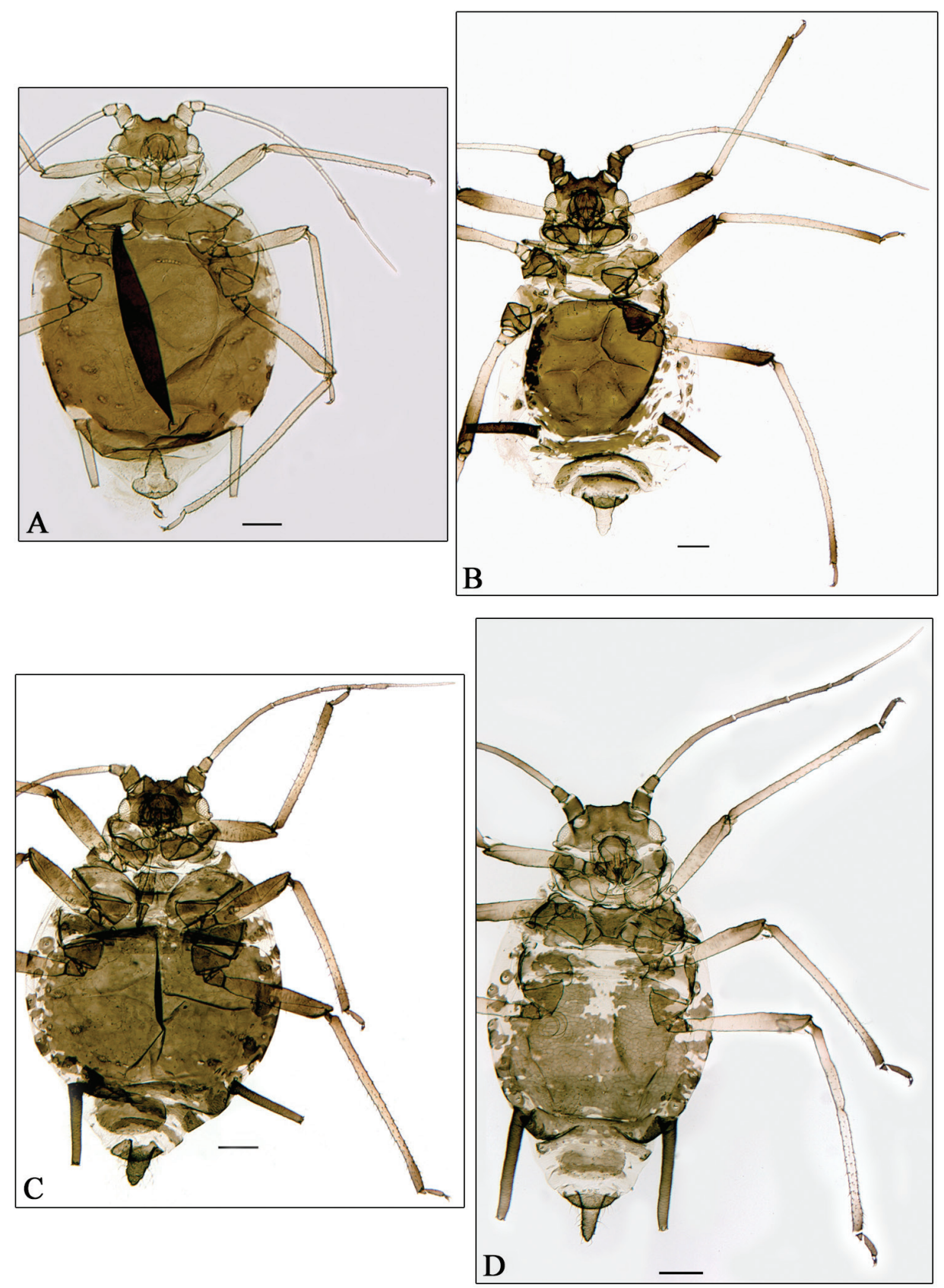

Figure 2. A Aphidura bozkhoae. B A. delmasi. C A. ornata. D A. pannonica. A-D apterous viviparous female. Scale bars $0.2 \mathrm{~mm}$.

In our opinion the synonymy can stand, because V. F. Eastop studied a wide number of specimens from diverse provenances (host plants, localities and dates), including types (R. L. Blackman, pers. com.), and also because of our observations, or at least it should be 
maintained in the sense that there is only one variable species involved. Nevertheless the valid name for this species could be $A$. mingens if the holotype of $A$. picta could be shown to be a fundatrix of $A$. ornata, in which case $A$. picta would be a synonym of that species.

Blackman and Eastop (2006) showed that Aphidura mordvilkoi and A. prinsepiae could be synonyms. Kadyrbekov (2013) established the synonymy. We have found differences between specimens identified as prinsepiae by Patshchenko and other ones identified as mordvilkoi by Shaposhnikov (Fig. 1D), similar to those shown by Kadyrbekov (2013). All of them can be considered to be a consequence of intraspecific variability. In conclusion, the established synonymy can be kept.

\section{New host plant and country records}

Collection data for the following first records are shown in Table 1.

Aphidura bozhkoae (Fig. 2A) is recorded for the first time on Prunus spinosa and on $P$. prostrata; it was previously recorded from several other species habitually placed in Prunus, although some of them can be classified in Cerasus or in Aflatunia.

Aphidura delmasi (Fig. 2B) is recorded for the first time on Silene viscosa; it has previously been recorded on other species of Silene.

Aphidura ornata (Fig. 2C) is recorded for the first time on Silene inaperta, S. nutans and $S$. saxifraga; it has been recorded previously on four other species of Silene.

Aphidura pannonica (Fig. 2D) is recorded for the first time on Gypsophila paniculata; this aphid has been previously recorded from several species of Silene.

Aphidura picta (Fig. 1C) is recorded for the first time (i) on Silene glauca and (ii) from Afghanistan. This aphid has been recorded on several species of Silene, and also of Dianthus; and it was known from Iran, Tajikistan and Pakistan, and other Asiatic and European countries.

\section{Aphidura pujoli, amendment of distribution}

The identification made by G. Remaudière, of four apterous viviparous females belonging to his sample 014072 from Pakistan, as $A$. pujoli is not correct; in fact these specimens belong to a new species, $A$. pakistanensis. In consequence the record of $A$. pujoli from Pakistan by Naumann-Etienne and Remaudière (1976) is incorrect, and A. pujoli (Fig. 3A) remains restricted to Europe, having been recorded from Portugal, Spain, France (including Corsica), Switzerland, Italy (including Sicily), and Ukraine.

\section{Aphidura delmasi, new morphs}

Collecting data in Table 1: fundatrix, sample 7876; oviparous females and males, sample 7591. 


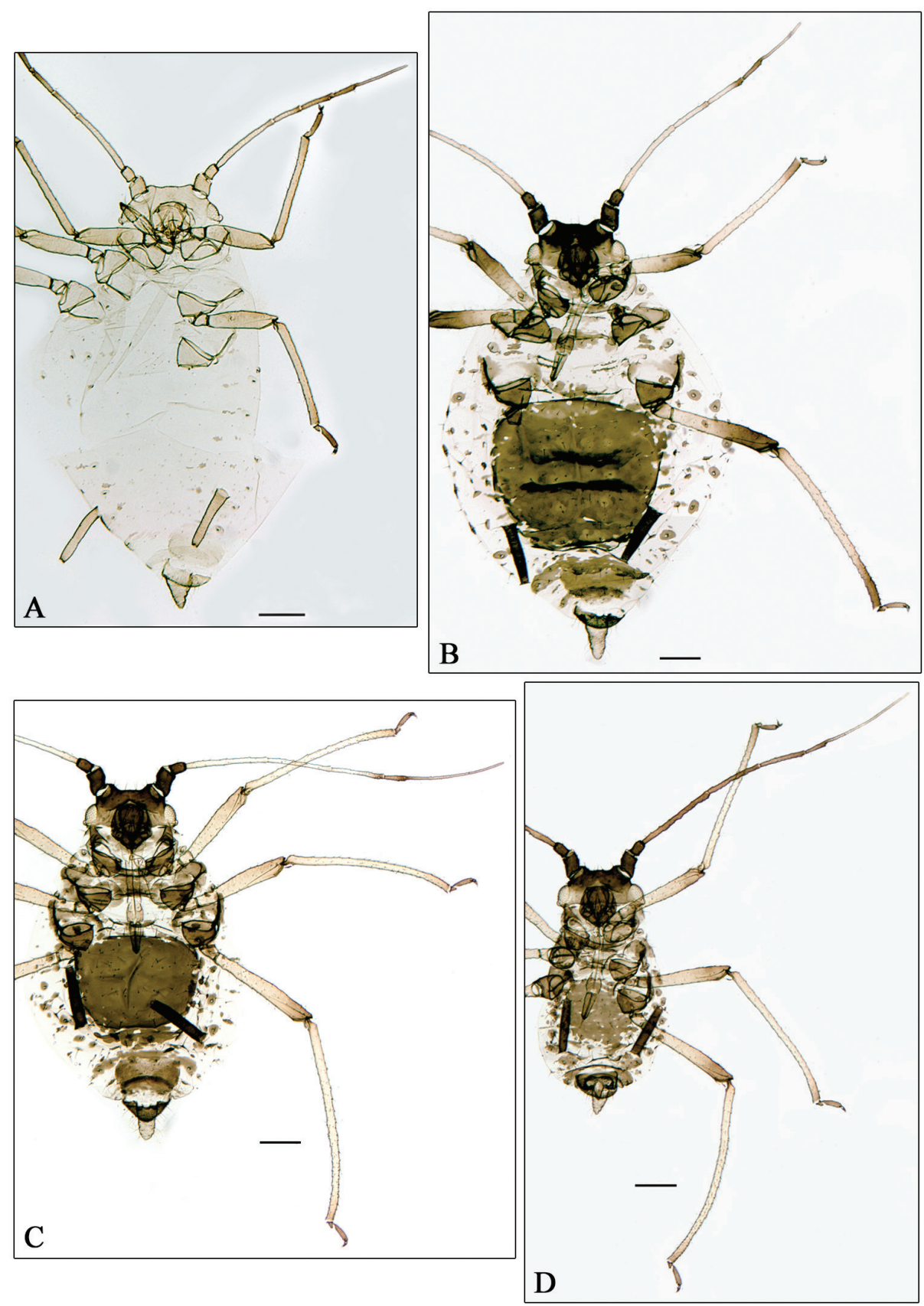

Figure 3. A Aphidura pujoli. B-D A. delmasi B fundatrix C oviparous female $\mathbf{D}$ male. Scale bars $0.2 \mathrm{~mm}$.

Fundatrix. From 4 specimens (Fig. 3B). Very similar to the fundatrigenous aptera described by Remaudière and Leclant (1965) and illustrated in detail by Mme. M. Arnault (page 719, figures 1-8), with shorter antennae, legs and siphunculi, as 
is normal in fundatrices, and without postsiphuncular sclerites. Metric and meristic features in Table 2.

Oviparous female. From 4 specimens (Fig. 3C). Very similar to the fundatrigenous aptera, with paler antennae, yellowish legs (only tarsi are smoky). Hind tibiae not swollen, with 20-30 scent plates. Metric and meristic features in Table 2.

Male. From 4 specimens (Fig. 3D). Apterous. Also very similar to the fundatrigenous aptera, but smaller, with paler legs (only tarsi are smoky) and longer antennae. Aedeagus and parameres brown. Metric and meristic features in Table 2.

\section{New species}

Six new species are established: $A$. gallica and $A$. amphorosiphon, which live on species of Silene, A. pakistanensis, A. graeca and A. urmiensis, which live on other caryophyllaceous plants (respectively species of Dianthus, Gypsophila and Spergula), and A. iranensis, which lives on Prunus.

\section{Aphidura gallica sp. $\mathbf{n}$.}

urn:Isid:zoobank.org:act:7C59AAC8-D440-4EAC-B376-047DA69F053A

http://species-id.net/wiki/Aphidura_gallica

Apterous viviparous female (Figs 4A, B). Colour in life unknown. Head yellowish brown with rugosity near the eyes. Antennal segments I-IV as pale as cephalic dorsum, and V and VI darker. Dorsal pigmentation and sclerotisation very variable. In several specimens, holotype included prothorax with complete but pale band, metathorax with brown spinopleural transverse band and setiferous marginal sclerites, abdominal segments 1-6 with an extensive dark spinopleural patch, partially fragmented in midline and with an irregular lateral margin partly incorporating the marginal sclerites; abdominal segments 7 and 8 with bands paler than patch. In other specimens, dorsum mainly membranous, with pale brown to brown pleural sclerites on abdominal segments 1-6, which are irregular in shape and sometimes joined between segments, and several very small and pale marginal setiferous sclerites. Other specimens have an intermediate degree of sclerotisation and pigmentation. Mesosternal mammariform processes yellowish, thin and tall. Siphunculi cylindrical, dark, and densely covered with denticulate scales. Cauda triangular (sometimes with a slight constriction) with pointed apex, and not darker than legs. Anal and genital plates as pale as cauda. Metric and meristic features in Table 3.

Alate viviparous female (Fig. 4C). Head brown, as dark as thorax. Abdominal segments 1 and 2 with spinal sclerites; segments 4-5 with spinopleural patch, sometimes partially joined with the spinopleural bands on 3 and 6; segments 1-6 with marginal sclerites; segment 7 with a band paler than previously mentioned sclerites; segment 8 with pale setiferous sclerites, sometimes coalesced together. Metric and meristic features in Table 3. 

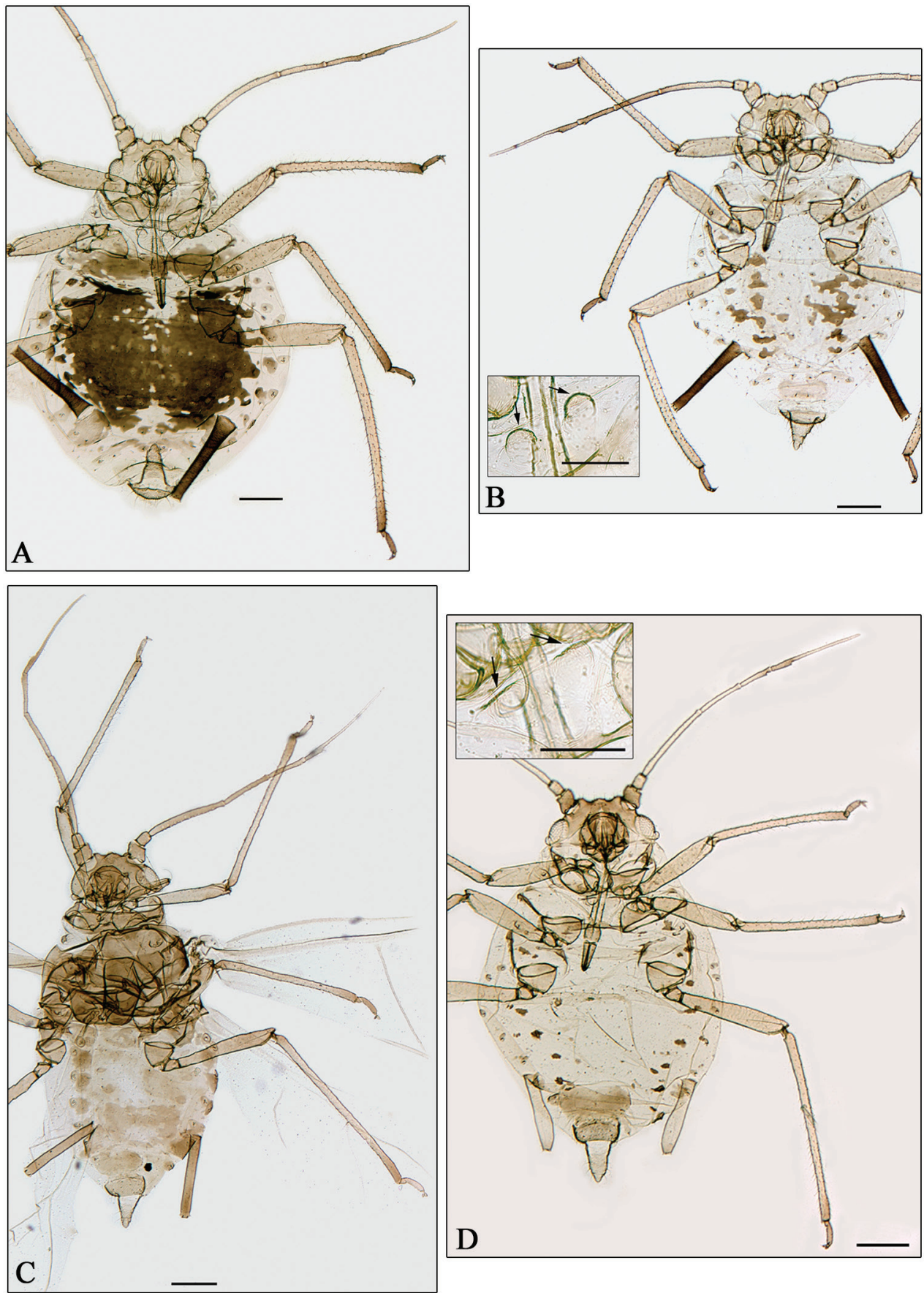

Figure 4. A-C Aphidura gallica sp. n. D A. amphorosiphon sp. n. A-B, D apterous viviparous female $\mathbf{C}$ alate viviparous female $\mathbf{A}$ pigmented form $\mathbf{B}$ unpigmented form $\mathbf{B}, \mathbf{D}$ boxes mesosternum with mammariform processes. General scale bars $0.2 \mathrm{~mm}$, boxes scale bar $0.01 \mathrm{~mm}$. 
Table 3. Metric and meristic features of Aphidura gallica sp. n. and A. amphorosiphon sp. n.; n, number of measured specimens.

\begin{tabular}{|c|c|c|c|c|c|}
\hline & A. gallica & A. gallica & \begin{tabular}{|c|}
$\begin{array}{c}\text { A. amphoro- } \\
\text { siphon }\end{array}$ \\
\end{tabular} & \begin{tabular}{|c|}
$\begin{array}{c}\text { A. amphoro- } \\
\text { siphon }\end{array}$ \\
\end{tabular} & $\begin{array}{l}\text { A. amphoro- } \\
\text { siphon }\end{array}$ \\
\hline & $\begin{array}{l}\text { Apt. viv. } \\
\text { femal. }\end{array}$ & Al. viv. femal. & Ap. viv. femal. & Al. viv. femal. & Male \\
\hline & $\mathbf{n}=\mathbf{3 0}$ & $\mathrm{n}=\mathbf{2}$ & $\mathrm{n}=12$ & $\mathbf{n}=3$ & $\mathrm{n}=1$ \\
\hline Body [mm] & $1.475-2.325$ & $1.600-1.725$ & $1.275-1.638$ & $1.100-1.525$ & 1.275 \\
\hline Antenna [mm] & $1.070-1.735$ & $1.343-1.343$ & $0.978-1.170$ & $1.265-1.615$ & $1.340-1.380$ \\
\hline Antenna / Body [times] & $0.66-0.93$ & $0.84-0.84$ & $0.71-0.89$ & $1.05-1.15$ & $1.05-1.08$ \\
\hline Ant. segm. III [mm] & $0.32-0.49$ & $0.23-0.36$ & $0.26-0.35$ & $0.35-0.40$ & $0.38-0.38$ \\
\hline Ant. segm. IV [mm] & $0.16-0.36$ & $0.12-0.22$ & $0.14-0.20$ & $0.20-0.28$ & $0.22-0.23$ \\
\hline Ant. segm. V [mm] & $0.14-0.26$ & $0.11-0.18$ & $0.13-0.18$ & $0.16-0.23$ & $0.17-0.19$ \\
\hline Ant. segm. VI base [mm] & $0.08-0.13$ & $0.10-0.10$ & $0.09-0.11$ & $0.10-0.13$ & $0.10-0.11$ \\
\hline $\begin{array}{l}\text { Ant. segm. VI processus } \\
\text { terminali } \mathrm{mm} \text { ] }\end{array}$ & $0.25-0.44$ & $0.37-0.37$ & $0.25-0.31$ & $0.32-0.48$ & $0.37-0.38$ \\
\hline $\begin{array}{l}\text { Ant. segm. VI processus } \\
\text { terminalis/ Ant. segm. III } \\
\text { [times] }\end{array}$ & $0.66-0.99$ & $1.04-1.04$ & $0.77-1.07$ & $0.85-1.22$ & 1.00 \\
\hline $\begin{array}{l}\text { Ant. segm. VI processus } \\
\text { terminalis/ base [times] }\end{array}$ & $2.88-4.08$ & $3.89-3.89$ & $2.57-3.08$ & $3.37-4.04$ & $3.57-3.70$ \\
\hline $\begin{array}{l}\text { Secondary sensoria, Ant. } \\
\text { segm. III [number] }\end{array}$ & 0 & $16-34$ & 0 & $16-21$ & $63-72$ \\
\hline $\begin{array}{l}\text { Secondary sensoria, Ant. } \\
\text { segm. IV [number] }\end{array}$ & 0 & 0 & 0 & 0 & $29-32$ \\
\hline $\begin{array}{l}\text { Secondary sensoria, Ant. } \\
\text { segm. V [number] }\end{array}$ & 0 & 0 & 0 & 0 & $11-15$ \\
\hline Ultimate rostral segm. $[\mathrm{mm}]$ & $0.11-0.15$ & $0.10-0.13$ & $0.12-0.14$ & $0.10-0.13$ & 0.10 \\
\hline $\begin{array}{l}\text { Ultimate rostral segm. / its } \\
\text { basal width [times] }\end{array}$ & $2.00-3.00$ & $2.00-2.60$ & $2.18-2.80$ & $2.88-2.88$ & 2.67 \\
\hline $\begin{array}{l}\text { Ultimate rostral segm. / Ant. } \\
\text { segm. VI base [times] }\end{array}$ & $1.10-1.87$ & $1.37-1.37$ & $1.12-1.42$ & $0.96-1.05$ & $0.95-1.00$ \\
\hline Hind femur $[\mathrm{mm}]$ & $0.39-0.60$ & $0.39-0.50$ & $0.35-0.46$ & $0.38-0.45$ & $0.42-0.43$ \\
\hline Hind tibia $[\mathrm{mm}]$ & $0.72-1.13$ & $0.81-1.02$ & $0.61-0.83$ & $0.80-1.00$ & $0.82-0.85$ \\
\hline Hind tibia / Body [times] & $0.43-0.59$ & $0.51-0.59$ & $0.45-.55$ & $0.58-0.73$ & $0.64-0.67$ \\
\hline Hind tarsus, 2nd segm. [mm] & $0.10-0.12$ & $0.11-0.11$ & $0.08-0.10$ & $0.10-0.11$ & $0.09-0.10$ \\
\hline $\begin{array}{l}\text { Hind tarsus, 2nd segm. / } \\
\text { Ultimate rostral segm. [times] }\end{array}$ & $0.70-0.95$ & $0.81-1.05$ & $0.67-0.83$ & $0.83-0.95$ & $0.90-0.95$ \\
\hline $\begin{array}{l}\text { Abdominal marginal papillae } \\
\text { [number] }\end{array}$ & 0 & 0 & 0 & 0 & 0 \\
\hline Siphunculus [mm] & $0.35-0.50$ & $0.35-0.42$ & $0.27-0.33$ & $0.25-0.30$ & 0.24 \\
\hline Siphundulus / Body [times] & $0.20-0.29$ & $0.22-0.24$ & $0.18-0.24$ & $0.18-0.24$ & 0.19 \\
\hline $\begin{array}{l}\text { Siphunculus / Ant. segm. III } \\
\text { [times] }\end{array}$ & $0.87-1.24$ & $0.99-1.84$ & $0.90-1.04$ & $0.65-0.77$ & $0.64-0.65$ \\
\hline $\begin{array}{l}\text { Siphunculus / its basal width } \\
\text { [times] }\end{array}$ & $4.00-5.57$ & $7.00-7.00$ & $3.60-5.80$ & $3.85-5.89$ & 5.33 \\
\hline $\begin{array}{l}\text { Siphuncular widths, maximal } \\
\text { / basal [times] }\end{array}$ & $0.50-0.86$ & $0.80-0.80$ & $0.83-1.20$ & $0.81-1.11$ & 1.33 \\
\hline
\end{tabular}




\begin{tabular}{|c|c|c|c|c|c|}
\hline & A. gallica & A. gallica & $\begin{array}{c}\text { A. amphoro- } \\
\text { siphon }\end{array}$ & $\begin{array}{c}\text { A. amphoro- } \\
\text { siphon }\end{array}$ & $\begin{array}{l}\text { A. amphoro- } \\
\text { siphon }\end{array}$ \\
\hline & $\begin{array}{l}\text { Apt. viv. } \\
\text { femal. }\end{array}$ & Al. viv. femal. & Ap. viv. femal. & Al. viv. femal. & Male \\
\hline & $\mathbf{n}=\mathbf{3 0}$ & $\mathrm{n}=\mathbf{2}$ & $\mathrm{n}=12$ & $\mathbf{n}=\mathbf{3}$ & $\mathrm{n}=\mathbf{1}$ \\
\hline $\begin{array}{l}\text { Siphuncular widths, maximal } \\
\text { / minimal [times] }\end{array}$ & $1.00-1.00$ & $1.00-1.00$ & $1.25-1.79$ & $1.47-2.00$ & 2.18 \\
\hline $\begin{array}{l}\text { Siphuncular minimal width } \\
\text { / Hind tibia, diameter at } \\
\text { middle [times] }\end{array}$ & $1.05-1.57$ & $1.33-1.69$ & $1.00-1.57$ & $1.00-.50$ & 0.61 \\
\hline Cauda $[\mathrm{mm}]$ & $0.15-0.24$ & $0.15-0.19$ & $0.14-0.19$ & $0.09-0.15$ & 0.09 \\
\hline Cauda / Siphunculus [times] & $0.36-0.50$ & $0.41-0.46$ & $0.45-0.62$ & $0.34-0.50$ & 0.38 \\
\hline Cauda / its basal width [times] & $1.07-1.32$ & $1.12-1.36$ & $1.10-1.46$ & $0.86-1.45$ & 0.78 \\
\hline \multicolumn{6}{|l|}{ Setae on ... } \\
\hline$\ldots$ Frons $[\mu \mathrm{m}]$ & $26-45$ & $23-23$ & $17-38$ & $15-21$ & 10 \\
\hline $\begin{array}{l}\text {... Frons / b. d. Ant. segm. III } \\
\text { [times] }\end{array}$ & $1.2-2.3$ & $1.6-1.6$ & $1.0-1.9$ & $0.8-1.2$ & 0.5 \\
\hline$\ldots$ Vertex $[\mu \mathrm{m}]$ & $23-35$ & $18-18$ & $10-23$ & $15-20$ & 13 \\
\hline $\begin{array}{l}\text {... Vertex / b. d. Ant. segm. } \\
\text { III [times] }\end{array}$ & $1.00-1.75$ & $1.3-1.3$ & $0.6-1.3$ & $0.8-1.1$ & 0.7 \\
\hline ... Ant. segm. III $[\mu \mathrm{m}]$ & $13-25$ & $15-20$ & $7-13$ & $7-10$ & 5 \\
\hline $\begin{array}{l}\text {... Ant. segm III / T. Ant. } \\
\text { segm. III [times] }\end{array}$ & $0.6-1.3$ & $0.7-1.5$ & $0.5-0.7$ & $0.4-0.6$ & 0.3 \\
\hline $\begin{array}{l}\text {... Ultimate rostral segm. } \\
\text { [number] }\end{array}$ & $10-16$ & $11-11$ & $11-17$ & $9-13$ & 12 \\
\hline$\ldots$ Hind femur, dorsal $[\mu \mathrm{m}]$ & $13-25$ & $13-20$ & $7-15$ & $10-15$ & 10 \\
\hline$\ldots$ Hind femur, ventral $[\mu \mathrm{m}]$ & $23-45$ & $25-28$ & $20-30$ & $17-23$ & 15 \\
\hline $\begin{array}{l}\ldots \text { Hind tibia, dorsal, at } \\
\text { middle }[\mu \mathrm{m}]\end{array}$ & $25-38$ & $25-28$ & $20-30$ & $20-23$ & 20 \\
\hline $\begin{array}{l}\text {... Hind tibia, dorsal / Tibial } \\
\text { diameter (at middle) [times] }\end{array}$ & $0.5-1.0$ & $0.8-0.9$ & $0.6-1.0$ & $0.8-0.9$ & 0.6 \\
\hline $\begin{array}{l}\text {... Hind tarsus, first segm. } \\
\text { [number] }\end{array}$ & $2-3$ & $2-3$ & $2-3$ & $2-3$ & $2-3$ \\
\hline$\ldots$ Abdominal segm. $2-4[\mu \mathrm{m}]$ & $13-23$ & $16-20$ & $7-13$ & $10-13$ & 7 \\
\hline $\begin{array}{l}\text {... Abdominal segm. 2-4 / T. } \\
\text { Ant. segm. III [times] }\end{array}$ & $0.6-1.1$ & $0.7-1.5$ & $0.4-0.8$ & $0.5-0.6$ & 0.4 \\
\hline$\ldots$ Abdominal segm. $8[\mu \mathrm{m}]$ & $23-38$ & $23-28$ & $22-33$ & $18-25$ & 23 \\
\hline $\begin{array}{l}\text {... Abdominal segm. } 8 \text { / T. } \\
\text { Ant. segm. III [times] }\end{array}$ & $1.1-2.0$ & $1.2-1.6$ & $1.0-2.0$ & $1.0-1.3$ & 1.1 \\
\hline $\begin{array}{l}\text {... Abdominal segm. } 8 \\
\text { [number] }\end{array}$ & $4-5$ & $4-4$ & $4-4$ & $4-4$ & 4 \\
\hline$\ldots$ Ventro-abdominal $[\mu \mathrm{m}]$ & $25-50$ & $28-33$ & $20-35$ & $25-33$ & 23 \\
\hline $\begin{array}{l}\text {... Genital plate, discal } \\
\text { [number] }\end{array}$ & $2-4$ & $2-2$ & $2-2$ & $2-2$ & - \\
\hline $\begin{array}{l}\text {... Genital plate, marginal } \\
\text { [number] }\end{array}$ & $10-17$ & $10-12$ & $10-16$ & $8-10$ & - \\
\hline ... Cauda [number] & $6-9$ & $8-8$ & $6-7$ & $6-6$ & 6 \\
\hline
\end{tabular}

NOTE. Used abbreviations: Al., Alate; Ant., Antennal; Apt., Apterous; b. d., basal diameter; femal., females; n, number of measured specimens; segm., segment; viv., viviparous. 
Types. Holotype: Apterous viviparous female (specimen 2), on Silene gallica, Banyuls-sur-Mer (Pyrénées Orientales), France, 11-VII-1957, Remaudière leg. (sample 4241). Paratypes: 39 apterous and 9 alate viviparous females with the same data that the holotype; plus 49 apterous viviparae on Silene paradoxa, Défilé de l'Inzecca (Haute Corse), 4-VI-1970, F. Leclant leg. (sample 4660) [Remaudière sample 17925].

Etymology. The specific name of the new species, gallica, is an adjective that refers to the Galia, France in times of the Roman Empire, in feminine; it is also coincident with the specific name of the host plant of the holotype.

Discussion. See the discussion of the following new species.

\section{Aphidura amphorosiphon sp. $\mathbf{n}$.}

urn:lsid:zoobank.org:act:812E7A5A-0BE0-4424-8661-38A7D0CC268C http://species-id.net/wiki/Aphidura_amphorosiphon

Apterous viviparous female (Fig. 4D). Colour in life unknown. Head yellowish brown to brown. Antennal segments II-III or II-V pigmented like cephalic dorsum, and I and IV-VI or only VI darker than others. Mesosternal mammariform processes rounded, low and pale. Several specimens (holotype included) are pale in general with dark brown intersegmental sclerites, brown postsiphuncular and spiracular sclerites, pale brown setiferous sclerites on abdominal segments $6-8$, sometimes coalescing together into transverse bands. The most pigmented specimen has a transverse spinopleural band on prothorax, fragmented bands on mesothorax and abdominal segments 1,6 and 7, fragmented spinopleural patches on abdominal segments $2-5$, and setiferous sclerites on metathorax and abdominal segments 1 and 8 . Siphunculi markedly swollen, with stem nearly smooth, and pale or with a smoky apical portion. Cauda triangular, sometimes with a slight constriction near the base, and as pale as the greater part of siphunculi and legs. Genital and anal plates as pale as cauda. Metric and meristic features in Table 3.

Alate viviparous female (Fig. 5A). Head brown, as pigmented as pro- and pterothorax and darker than antennae, tarsi and distal portions of femora and tibiae. Abdominal segments 3-5 with a spinopleural patch, and 7-8 with transverse bands. Siphunculi as dark as pigmented parts of femora. Other qualitative features as in apterae. Metric and meristic features in Table 3.

Male. Winged. Qualitatively very similar to alate viviparous females; with dark parameres. Metric and meristic features in Table 3.

Types. Holotype: Apterous viviparous female (specimen 5), on Silene sp. Kuh-e Dinar (Kohgiluyed and Boyer-Ahmad), Iran, 14-IX-1955, Remaudière leg. (sample i1 118a). Paratypes: 15 apterous, 2 viviparous females and 1 male with the same data that the holotype; plus 1 apterous viviparae and 2 alate viviparae on an unidentified species of Caryophyllaceae, Chalus [road to Amol] (Mazenderan), Iran, 3-V-1963, Remaudière leg. (sample i2417). 


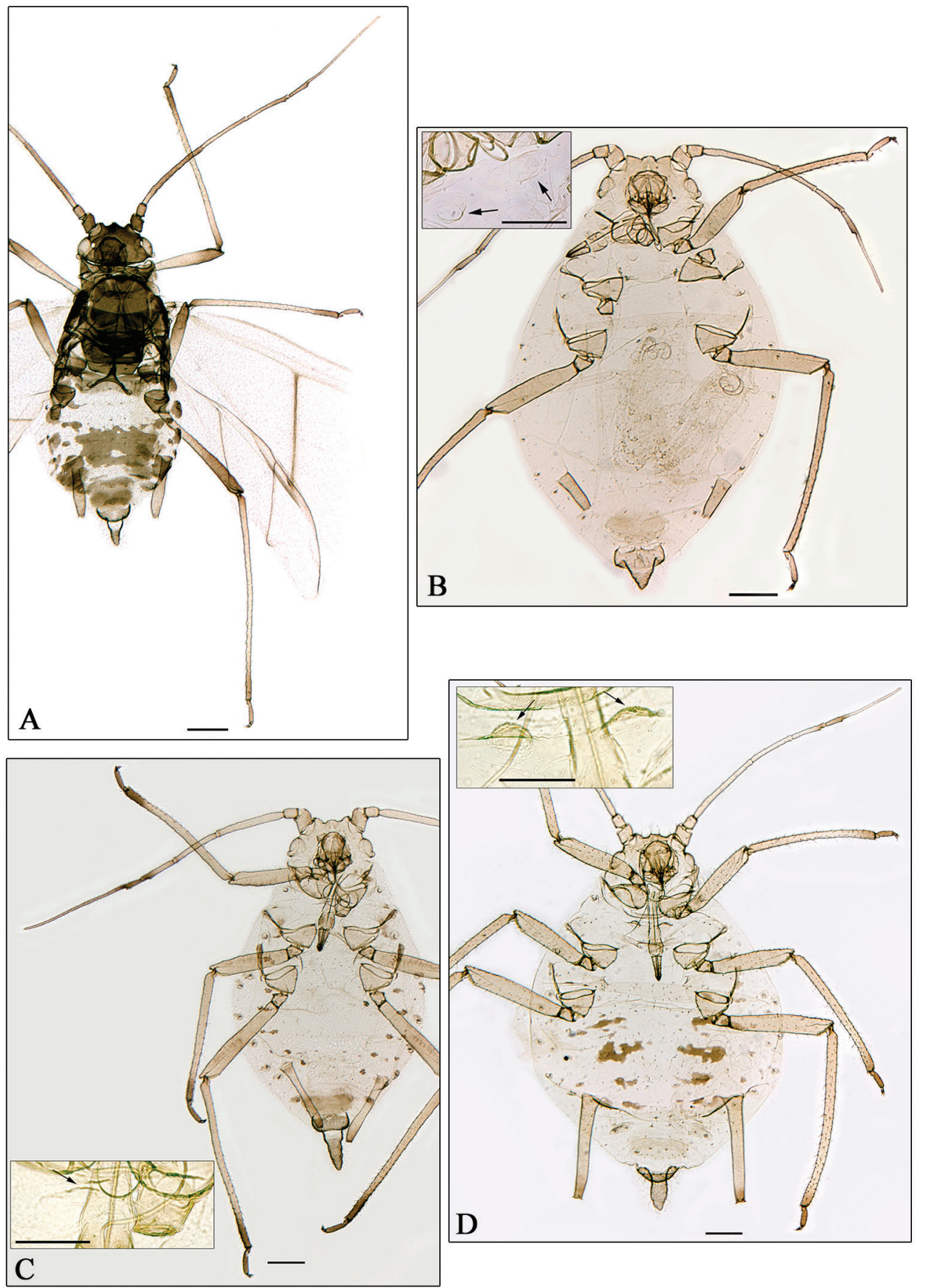

Figure 5. A Aphidura amphorosiphon sp. n. B A. pakistanensis sp. n. C A. graeca sp. n. D A. urmiensis sp. n. A alatae viviparous female B-D apterous viviparous female B-D boxes mesosternum with mammariform processes. General scale bars $0.2 \mathrm{~mm}$, boxes scale bar $0.01 \mathrm{~mm}$. 
Etymology. The specific name is a neutral noun in apposition, formed for the Greek words "amphora" and "siphon", which respectively mean flask and siphon, like in the genus Amphorosiphon.

Discussion. The distinctive features of $A$. amphorosiphon sp. n. and A. gallica sp. $\mathrm{n}$. are summarized in the identification key to apterae of Aphidura in the general discussion, and in the following modification to the key to aphids on Silene (Blackman and Eastop 2006) for addition of Aphidura amphorosiphon and A. gallica (Aphidura spp. from Iran and from France respectively in that key), and also $A$. massagetica and A. nomadica, which have been recently described (Kadyrbekov 2013), with deletion of couplets 28 to 34, although several propositions have been partially or completely reutilised:

27 Anterior part of mesosternum without mammariform processes [rest of the proposition without modification]

Volutaphis schusteri

- $\quad$ Anterior part of mesosternum with a pair of mammariform processes [rest of the proposition without modification] SIPH markedly clavate (distal maximum width habitually at least 1.2 times basal minimum).

- $\quad$ SIPH cylindrical, subcylindrical, tapering from base to apex (sometimes outward curved), or slightly clavate (distal maximum width at most 1.2 times basal minimum width).

36 Tergum with an extensive almost solid black shield extending over metanotum and ABD TERG 1-6, usually incorporating marginal sclerites.

Aphidura ornatella

- $\quad$ Tergum pale or with variable sclerotisation, sometimes extensive but with large windows spinally and marginally, not forming a solid black shield ...37

37 ANT PT/BASE 2.55-3.1. RIV+V 1.2-1.5 times HT II. SIPH light with smoky apex. Cauda 1.1-1.5 times its basal width , with 6-7 hairs. Abdomen variably sclerotised and pigmented

Aphidura amphorosiphon ANT PT/BASE 3.2-3,9. RIV+V 1-1.2 times HT II. SIPH uniformly pigmented. Cauda 1.1-1.2 times its basal width, with 7-11 hairs. ABD TERG 1-6 with a dark central patch and marginal sclerites .... Aphidura nomadica

38 SIPH pale or dusky, slightly clavate, 1.5-1.8 times cauda, which is short triangular. Tergum without sclerotisation, completely pale ....Aphidura pujoli

- $\quad$ SIPH brown to black at least in part, sometimes slightly clavate, 1.9-2.8 times cauda. Tergum with variable sclerotisation and pigmentation, rarely complete pale.

39 ABD TERG 2-3 with longest hairs 35-55 $\mu \mathrm{m}$ long, 1.5-2.0 times ANT BD III. ANT I long, 1.3-1.5 times its maximal width. Dorsal abdomen with a large central oval sclerite on ABD TERG (1)2-5 Aphidura delmasi

- $\quad$ ABD TERG 2-3 with longest hairs 4-25 $\mu \mathrm{m}$ long, 0.2-1.1 times ANT BD III. ANT I short, 1.1 times its maximal width at most. Dorsal abdomen with 
variable sclerotisation and pigmentation, but rarely with a central oval sclerite on ABD TERG 2-5

40 Tergum with an extensive almost solid black shield extending over metanotum and ABD TERG 1-6, usually incorporating marginal sclerites. Cauda dark broad triangular, longer than 2 times its basal width and usually shorter than 0.5 times SIPH, and with 10-16 hairs

Aphidura ornata

- $\quad$ Tergum pale or with variable sclerotisation, sometimes extensive but with large windows spinally and marginally, not forming a solid black shield. Cau$\mathrm{da}$ variable in shape, proportions and colour.

41 Cauda tongue-shaped, 1.4-1.8 times its basal width 42 Cauda triangular, although sometimes with a slight constriction, 1.05-1.4 times its basal width.

ANT PT/BASE 4.0-5.7. Hairs on ANT III and ABD TERG 2-3 minute, maximally $4-7 \mu \mathrm{m}$ long, $0.15-0.3$ times BD III. SIPH 2.2-2.8 times cauda...

Aphidura pannonica

- $\quad$ ANT PT/BASE 2.5-4.0. Hairs on ANT III and ABD TERG 2-3 maximally 8-22 $\mu \mathrm{m}, 0.4-1.0$ times BD III. SIPH 1.9-2.5 times cauda...Aphidura picta $\mathrm{RIV}+\mathrm{V}$ 0.9-1.0 times HT II, with 8-10 accessory hairs. Cauda 1.3-1.4 times its basal width. Hairs on ABD TERG 2-3 8-11 $\mu \mathrm{m}$ long, 0.3-0.5 times BD III Aphidura massagetica

- $\quad$ RIV+V 1.05-1.45 times HT II, with 10-16 accessory hairs. Cauda 1.051.35 times its basal width. Hairs on ABD TERG 2-3 13-23 $\mu \mathrm{m}$ long, 0.6-1 times BD III

Aphidura gallica

\section{Aphidura pakistanensis sp. $\mathbf{n}$.}

urn:lsid:zoobank.org:act:D3B0B038-D4A8-41E8-803A-0D2CFE97A8CE http://species-id.net/wiki/Aphidura_pakistanensis

Apterous viviparous female (Fig. 5B). Colour in life unknown. Antennae, rostrum, legs, siphunculi, genital plate and cauda yellowish. Frontal tubercles low. Mesosternal mammariform processes low, rough and pale, sometimes inconspicuous. Dorsum of thorax and abdomen without segmental sclerites; intersegmental and spiracular sclerites inconspicuous. The characteristic spinules on postsiphuncular area and tergum of abdominal segments 7 and 8 are dispersed and delicate. Siphunculi short, slightly swollen and densely covered with scales. Cauda short triangular, with broad basis. Metric and meristic features in Table 4.

Types. Holotype: Apterous viviparous female (specimen 1), on Dianthus sp. Kalam (Khyber Pakhtunkhwa), Pakistan, 1800 m, 17-VIII-1991, Naumann-Etienne leg. [Remaudière's sample 014072]. Paratypes: 3 apterous viviparous females with the same data that the holotype.

Etymology. The specific name of the new species is an adjective that refers to Pakistan, in feminine. 
Table 4. Metric and meristic features of apterous viviparous females of Aphidura pakistanensis sp. n., A. graeca sp. n., A. urmiensis sp. n., and A. iranensis sp. n.; n, number of measured specimens.

\begin{tabular}{|c|c|c|c|c|}
\hline & A.pakistanensis & A. graeca & A. urmiensis & A. iranensis \\
\hline & $n=4$ & $\mathbf{n}=\mathbf{1}$ & $\mathbf{n}=\mathbf{2 0}$ & $n=6$ \\
\hline Body $[\mathrm{mm}]$ & $1.725-1.850$ & 1.838 & $1.900-2.125$ & $1.100-1.300$ \\
\hline Antenna $[\mathrm{mm}]$ & $1.053-1.655$ & 1.670 & $1.333-1.755$ & $1.005-1.210$ \\
\hline Antenna / Body [times] & $0.59-0.89$ & 0.91 & $0.67-0.84$ & $0.80-1.08$ \\
\hline Ant. segm. III [mm] & $0.32-0.49$ & $0.37-0.40$ & $0.39-0.52$ & $0.30-4.33$ \\
\hline Ant. segm. IV [mm] & $0.15-0.26$ & $0.26-0.26$ & $0.21-0.34$ & $0.16-0.20$ \\
\hline Ant. segm. V [mm] & $0.14-0.20$ & $0.19-0.2$ & $0.15-0.21$ & $0.14-0.16$ \\
\hline Ant. segm. VI base [mm] & $0.11-0.14$ & 0.14 & $0.09-0.12$ & $0.08-0.10$ \\
\hline Ant. segm. VI [mm] & $0.22-0.31$ & 0.56 & $0.30-0.44$ & $0.31-0.35$ \\
\hline $\begin{array}{l}\text { Ant. segm. VI processus terminalis/ Ant. } \\
\text { segm. III [times] }\end{array}$ & $0.63-0.80$ & 1.51 & $0.65-0.95$ & $0.96-1.13$ \\
\hline Ant. segm. VI processus terminalis/ base [times] & $2.00-2.39$ & 4.00 & $2.78-4.00$ & $3.18-4.53$ \\
\hline Ultimate rostral segm. $[\mathrm{mm}]$ & $0.10-0.12$ & 0.13 & $0.13-0.15$ & $0.10-0.11$ \\
\hline Ultimate rostral segm. / its basal width [times] & $1.10-2.00$ & 1.86 & $2.36-2.64$ & $2.20-2.50$ \\
\hline $\begin{array}{l}\text { Ultimate rostral segm. / Ant. segm. VI base } \\
\text { [times] }\end{array}$ & $0.85-1.00$ & 0.93 & $1.17-1.61$ & $1.08-1.26$ \\
\hline Hind femur $[\mathrm{mm}]$ & $0.39-0.52$ & $0.55-0.54$ & $0.48-0.59$ & $0.33-0.37$ \\
\hline Hind tibia $[\mathrm{mm}]$ & $0.73-0.95$ & $0.92-0.92$ & $0.86-1.05$ & $0.63-0.70$ \\
\hline Hind tibia / Body [times] & $0.41-0.51$ & $0.50-0.50$ & $0.44-0.52$ & $0.49-0.62$ \\
\hline Hind tarsus, 2nd segm. [mm] & $0.11-0.13$ & $0.14-0.13$ & $0.10-0.12$ & $0.09-0.10$ \\
\hline $\begin{array}{l}\text { Hind tarsus, 2nd segm. / Ultimate rostral } \\
\text { segm. [times] }\end{array}$ & $1.05-1.20$ & $1.04-1.00$ & $0.69-0.81$ & $0.84-0.95$ \\
\hline Abdominal Marginal papillae [number] & 0 & 0 & 0 & (0)2-4 \\
\hline Siphunculus [mm] & $0.17-0.20$ & 0.39 & $0.47-0.58$ & $0.26-0.31$ \\
\hline Siphundulus / Body [times] & $0.09-0.11$ & 0.21 & $0.23-0.29$ & $0.21-0.27$ \\
\hline Siphunculus / Ant. segm. III [times] & $0.41-0.56$ & 1.04 & $1.11-1.36$ & $0.79-1.02$ \\
\hline Siphunculus / its basal width [times] & $2.62-3.18$ & 5.50 & $4.14-5.50$ & $3.86-6.56$ \\
\hline Siphuncular widths, maximal / basal [times] & $0.69-0.82$ & 0.79 & $0.44-0.67$ & $0.61-0.89$ \\
\hline Siphuncular widths, maximal / minimal [times] & $1.00-1.06$ & 1.38 & $1.00-1.00$ & $1.06-1.13$ \\
\hline $\begin{array}{l}\text { Siphuncular minimal width / Hind tibia, } \\
\text { diameter at middle [times] }\end{array}$ & $1.42-1.50$ & 0.94 & $1.24-1.65$ & $1.25-1.89$ \\
\hline Cauda $[\mathrm{mm}]$ & $0.11-0.14$ & 0.23 & $0.18-0.24$ & $0.11-0.12$ \\
\hline Cauda / Siphunculus [times] & $0.55-0.82$ & 0.60 & $0.33-0.45$ & $0.37-0.40$ \\
\hline Cauda / its basal width [times] & $0.71-.00$ & 1.80 & $1.20-1.60$ & $0.92-1.05$ \\
\hline \multicolumn{5}{|l|}{ Setae on ... } \\
\hline$\ldots$ Frons $[\mu \mathrm{m}]$ & $8-10$ & 9 & $33-45$ & $5-10$ \\
\hline ... Frons / b. d. Ant. segm. III [times] & $0.38-0.44$ & 0.39 & $1.40-2.12$ & $0.25-0.67$ \\
\hline$\ldots$ Vertex $[\mu \mathrm{m}]$ & $8-10$ & 8 & $25-40$ & 8 \\
\hline ... Vertex / b. d. Ant. segm. III [times] & $0.38-0.57$ & 0.3 & $1.1-1.9$ & $0.4-0.5$ \\
\hline ... Ant. segm. III $[\mu \mathrm{m}]$ & $8-10$ & 10 & $14-21$ & $5-8$ \\
\hline ... Ant. segm III / b. d. Ant. segm. III [times] & $0.4-0.6$ & 0.4 & $0.6-0.9$ & $0.3-0.5$ \\
\hline ... Ultimate rostral segm. [number] & $5-7$ & 13 & $10-15$ & $8-11$ \\
\hline$\ldots$ Hind femur, dorsal $[\mu \mathrm{m}]$ & $10-13$ & 5 & $13-20$ & $3-5$ \\
\hline$\ldots$ Hind femur, ventral $[\mu \mathrm{m}]$ & $13-18$ & 13 & $25-40$ & $8-10$ \\
\hline$\ldots$ Hind tibia, dorsal, at middle $[\mu \mathrm{m}]$ & $20-25$ & 18 & $25-38$ & $15-23$ \\
\hline
\end{tabular}




\begin{tabular}{|c|c|c|c|c|}
\hline & A.pakistanensis & A. graeca & A. urmiensis & A. iranensis \\
\hline & $\mathrm{n}=4$ & $\mathrm{n}=1$ & $\mathrm{n}=\mathbf{2 0}$ & $\mathrm{n}=6$ \\
\hline $\begin{array}{l}\text {.. Hind tibia, dorsal / Tibial diameter (at } \\
\text { middle) [times] }\end{array}$ & $0.7-0.8$ & 0.41 & $0.6-0.9$ & $0.6-0.9$ \\
\hline ... Hind tarsus, first segm. [number] & $2-3$ & $2-3$ & $2-3$ & $2-3$ \\
\hline ... Abdominal segm.s $2-4[\mu \mathrm{m}]$ & $10-10$ & 3 & $15-23$ & $4-8$ \\
\hline $\begin{array}{l}\text {... Abdominal segm.s 2-4 / b. d. Ant. segm. } \\
\text { III [times] }\end{array}$ & $0.4-0.6$ & 0.11 & $0.7-1.1$ & $0.2-0.4$ \\
\hline$\ldots$ Abdominal segm. $8[\mu \mathrm{m}]$ & $20-25$ & 10 & $23-38$ & $8-15$ \\
\hline $\begin{array}{l}\text {... Abdominal segm. } 8 \text { / b. d. Ant. segm. III } \\
\text { [times] }\end{array}$ & $1.0-1.4$ & 0.44 & $1.0-1.8$ & $0.4-0.9$ \\
\hline ... Abdominal segm. 8 [number] & $4-5$ & 2 & $3-5$ & 4 \\
\hline$\ldots$ Ventro-abdominal $[\mu \mathrm{m}]$ & $20-38$ & 28 & $30-45$ & $11-16$ \\
\hline ... Genital plate, discal [number] & 2 & 2 & 2 & 2 \\
\hline ... Genital plate, marginal [number] & $10-14$ & 13 & $9-18$ & $7-10$ \\
\hline ... Cauda [number] & $6-8$ & 7 & $9-14$ & $6-6$ \\
\hline
\end{tabular}

NOTE. Used abbreviations: Ant., Antennal; b. d., basal diameter; n, number of measured specimens; segm., segment.

Discussion. Aphidura pakistanensis sp. $\mathrm{n}$. is the third species of the genus living on Dianthus. Its distinctive features are summarized in the identification key to apterae of Aphidura in the general discussion, and in the following modification to the key to aphids on Dianthus (Blackman and Eastop 2006) for addition of $A$. pakistanensis:

$7 \quad$ ABD TERG 1 and 7 without MTu. SIPH subcylindrical or slightly swollen̨. Anterior part of mesosternum with a pair of spinal mammariform processes...7A ABD TERG 1 and 7 with MTu. SIPH tapering from base to flange, with no trace of swelling. Anterior part of mesosternum without a pair of spinal mammariform processes

7A Cauda as long as its basal width or shorter. SIPH not longer than $0.20 \mathrm{~mm}$ and 0.6 times ANT III. Mesosternal processes small and pale, sometimes inconspicuous. Abdomen without dorsal pigmentation ......Aphidura pakistanensis

- $\quad$ Cauda longer than its basal width. SIPH longer than $0.26 \mathrm{~mm}$ and 0.60 times ANT III. Mesosternal processes pale or pigmented, always conspicuous. Abdomen pale or variably pigmented ................................................. 8

8 [without modification] Aphidura picta [without modification] Aphidura pujoli

\section{Aphidura graeca sp. $\mathbf{n}$.}

urn:lsid:zoobank.org:act:927C4017-2E8C-417E-BDBD-2A3262557025

http://species-id.net/wiki/Aphidura_graeca

Apterous viviparous female (Fig. 5C). Colour in life unknown. Head pale yellow. Antennal segment I-IV and proximal half of $\mathrm{V}$ as pale as cephalic dorsum, distal part of 
$\mathrm{V}$ and VI yellow brown. Dorsum of thorax and abdomen membranous and pale, with yellowish brown spiracular and brown intersegmental sclerites. Mesosternal mammariform processes low, rugose and pale. Siphunculi gently and asymmetrically swollen, rugose and more-or-less pigmented like tibiae. Cauda tongue-shaped with broad apex, pigmented like siphunculi. Anal and genital plates as pale as cauda. Metric and meristic features in Table 4.

Types. Holotype: Apterous viviparous female, on Gypsophila sp., Veria [road to Kastania] (Imanthia), Greece, 18-VI-1964, G. Remaudière leg. (sample 03026).

Etymology. The specific name of the new species is an adjective that means inhabitant of Greece, in feminine.

Discussion. Aphidura graeca sp. n. lives on Gypsophila, as does A. gypsophilae, and also $A$. pannonica, which has been above recorded on this plant-genus for first time. The distinctive features of Aphidura graeca are summarized in the identification key to apterae of Aphidura in the general discussion and in the following modification to the key to aphids on Gypsophila (Blackman and Eastop 2006), to include A. graeca and $A$. pannonica, and also $A$. naimanica and $A$. togaica, which have recently been described (Kadyrbekov 2013):

3 Anterior part of mesosternum with a pair of mammariform processes, ornamented with spinules .............................................................. 3A

- $\quad$ Anterior part of mesosternum without a pair of mammariform processes ... 4

3A SIPH markedly clavate........................................................

- SIPH not markedely clavate.......................................................... 3C

3B ANT PT at least 1.40 times ANT III. Abdominal dorsum mostly membranous, and pale. SIPH pale....

Aphidura graeca

- $\quad$ ANT PT at most 1.20 times ANT III. Abdominal dorsum with pigmented patches and sclerites. SIPH pigmented......................Aphidura naimanica

3C Head, prothorax (with a complete or fragmented transversal band) and SIPH brown. Abdominal spinopleural patch variably developed and pigmented and sometimes fragmented or (often in small specimens) absent

Aphidura pannonica

- Head, prothorax and SIPH (sometimes brownish apicad) pale. Abdomen variable sclerotised and pigmented ..............................................3C

3D ANT PT/BASE 3.4-4.4. R IV+V at least 1.0 times HT II ...Aphidura togaica ANT PT/BASE 5.0-5.5. R IV+V shorter than HT II ...Aphidura gypsophilae

\section{Aphidura urmiensis sp. n.}

urn:Isid:zoobank.org:act:41642023-E1EE-4E82-BD61-931EF3866450

http://species-id.net/wiki/Aphidura_urmiensis

Apterous viviparous female (Fig. 5D). Colour in life unknown. Head yellowish brown to brown. Clypeus bigger than those of the other species of Aphidura. Antennae 
yellowish brown, with brown segment VI, distal $1 / 3$ of V, and articulation between IV and V. Mesosternal mammariform processes well separated from one another, pale and round. Intersegmental sclerites small and dark brown; spiracular sclerites on segment 7 wider and darker than other abdominal spiracular sclerites; abdominal segments 3-6 with pleural and sometimes very small setiferous spinal sclerites, or with spinopleural sclerites; abdominal terga 7 and 8 pale. Siphunculi with narrow base, cylindrical (usually with slight outward curve) or slightly swollen, and as pale as tibiae. Cauda tongueshaped, pale like genital and anal plate. Metric and meristic features in Table 4.

Types. Holotype: Apterous viviparous female (specimen 5), on Spergula marina, Shahi island, Lake Urmia (East Azerbaijan), Iran, 5-VIII-1955, Remaudière leg. (sample i962). Paratypes: 42 apterous with the same data that the holotype; plus 6 apterous viviparae on S. marina, Charimboulaki, Lake Urmia (West Azerbaijan), Iran, 9-VIII1955, Remaudière leg. (sample i004a).

Etymology. The specific name, urmiensis is an adjective that refers to lake Urmia, in feminine, from the name of the Catholic Chaldean Archdiocese of Urmia.

Discussion. The distinctive features of A. urmiensis sp. n., which lives on Spergula marina are summarized in the identification key to apterae of Aphidura in the general discussion and in the following modification to key to aphids on Spergula and Spergularia (Blackman and Eastop 2006) for addition of Aphidura urmiensis:

Anterior part of mesosternum with a pair of spinal mammariform processes ..

Aphidura urmiensis

- $\quad$ Anterior part of mesosternum without a pair of spinal mammariform processes

\section{Aphidura iranensis sp. $\mathbf{n}$.}

urn:lsid:zoobank.org:act:B6A4D5D2-4826-4C5D-AF94-EFE0DCFF4A2C http://species-id.net/wiki/Aphidura_iranensis

Apterous viviparous female (Fig. 6A). Colour in life unknown. Head brown. Vertex with spinules disposed in scattered groups. Prothorax and at least some of abdominal segment 2-4 with small marginal tubercles; abdominal segment 8 with 0-2, most frequently 1 , small spinal tubercles. Mesosternal mammariform processes rounded and pale. Dorsal pigmentation and sclerotisation very variable. In several specimens (holotype included) prothorax with a complete band, mesothorax with a band with lateral windows, metathorax with two large spinopleural sclerites; abdominal segments 1-5 with several setiferous marginal sclerites, and a spinopleural patch, which has irregular edges and windows and may be coalesced with the metathoracic sclerites; abdominal segment 6 with small intersiphuncular and two postsiphuncular sclerites; segments 7 and 8 with brownish band; intersegmental sclerites are embodied in the above; spiracular sclerites inconspicuous. In less sclerotized and paler specimens the bands and patch 


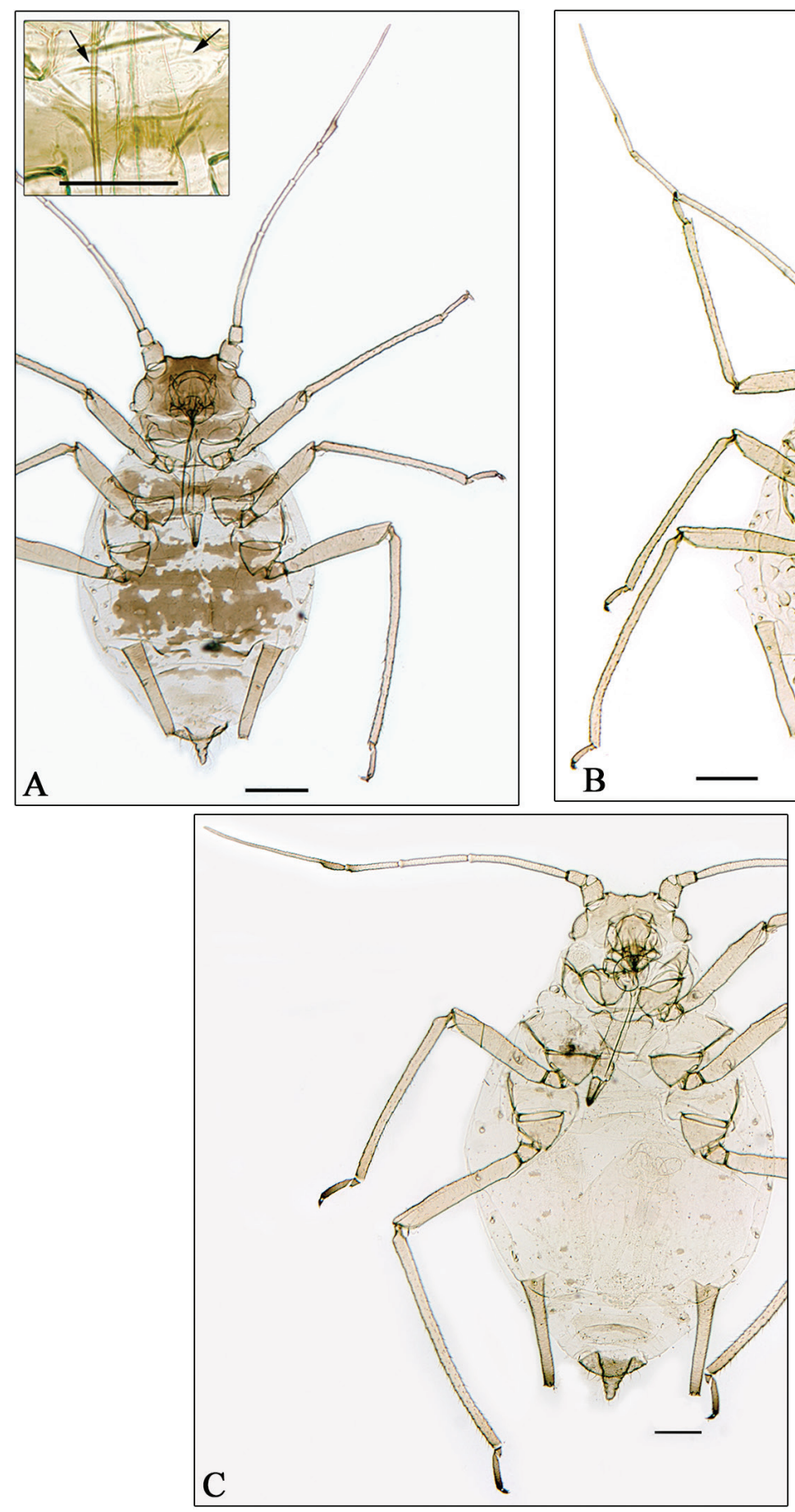

Figure 6. A Aphidura iranensis sp. n. B A. acanthophylli C A. gypsophilae A-C apterous viviparous female A box mesosternum with mammariform processes. General scale bars $0.2 \mathrm{~mm}$, box scale bar $0.01 \mathrm{~mm}$. 
are broken. Siphunculi slightly swollen, ornamented with denticulate scales, and paler than cephalic dorsum and dorsal thoracic-abdominal sclerotized areas. Cauda thin triangular, paler than siphunculi. Genital plate pale; anal plate coloured like cauda. Metric and meristic features in Table 4.

Types. Holotype: Apterous viviparous female (specimen 1), on Prunus sp., Khoy [30 km North] (West Azerbaijan), Iran, 1700 m, 7-VIII-1955, G. Remaudière leg. (sample i982). Paratypes: 5 apterous viviparous females, with the same collecting data as holotype.

Etymology. The specific name of the new species, iranensis, is an adjective that refers to Iran, in feminine.

Discussion. Aphidura iranensis sp. $\mathrm{n}$. is the second species of the genus living on species of Prunus. Its distinctive features are summarized in the identification key to apterae of Aphidura in the general discussion, and in the following modification to the key to aphids on Prunus (Blackman and Eastop 1994) for addition of A. iranensis:

$7 \quad$ [without modification]

- Head capsule with spiculose (sometimes delicate) or nodulose ornamentation

32 Anterior part of mesosternum with a pair of spinal mammariform processes, ornamented with spinules (Fig. 89B) ..................................................32B

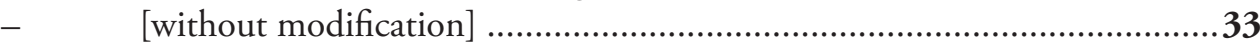

32B A continuous sclerotic and dark shield on (metanotum)ABD TERG 1-6(7), including marginal areas; and dorsum of other thoracic segments with sclerotic dark bands. ABD TERG 1-4 without marginal tubercles, and ABD TERG 8 without spinal tubercles.

Aphidura bozhkoae

- $\quad$ A continuous dorsal sclerotic shield absent; dorsum of thoracic segments with sclerotic bands, and ABD TERG 1-5(7) with spinal and pleural sclerites or patches, which may be coalescing. ABD TERG 2-4 frequently with marginal tubercles, and ABD TERG 8 frequently with spinal tubercles

Aphidura iranensis

\section{General discussion}

The features that distinguish the apterous viviparous females of the Aphidura species which share host plants have been described in the modifications to Blackman and Eastop's keys to aphids on different plant genera (Blackman and Eastop 1994, 2006) in the particular discussion of each new species.

The previously known and the new species together can be distinguished from each other using the following key to apterous viviparous females of species of Aphidura. In brackets are: (1) morphological characters that do not have correspondence in the other proposition of the disjunctive, but which are useful to confirm identification; (2) host plants, and distribution data; and (3) illustration reference. In the distribution of each species the countries are in geographical order from West to East, so that a quick general 
assessment of the distribution of each species can be made. The key uses data of species recently described from the respective original descriptions (Kadyrbekov 2013); other data are from literature and personal observations. A. melandrii is accessible by two routes, because several specimens have slightly swollen siphunculi (maximal swollen width at least 1.2 times minimal stem width) and others have conspicuously swollen siphunculi.

\section{Key to apterous viviparous females of Aphidura species of the world}

$1 \quad$ Siphunculi markedly swollen (maximal swollen width at least 1.2 times minimal stem width).

- Siphunculi of different form (cylindrical, subcylindrical, tapering or slightly swollen, see above "generic characters" section) Most of dorsal setae placed on conical tubercles. [Dorsum without segmental pigmented sclerotisation. On Acanthophyllum sp.; Iran. Fig. 6B]

Dorsal setae not placed on tubercles.

Mesosternal processes and cauda more or less pigmented, light brown to brown .... Siphunculi dark brown, 2.3-2.7 times cauda which has 7-11 setae. Abdominal dorsum with spino-pleural patch, postsiphuncular sclerites pigmented and marginal sclerites. [Ultimate rostral segment 1.0-1.2 times second segment of hind tarsi. Cauda 1.1-1.2 times its basal width. On Silene suffrutescens and S. sp.; Kazakhstan. Kadyrbekov (2013): fig. 8] Siphunculi pale, sometimes with smoky apex, 1.6-2.2 times cauda, which has 6-7 setae. If a spino-pleural patch present then ultimate rostral segment is 1.2-1.5 times second segment of hind tarsi Antennal segment VI processus terminalis at least 1.4 times antennal segment III and approximately 4 times antennal segment VI base. Longest dorsal setae on abdominal segment 2-4 approximately $3 \mu \mathrm{m}$. Cauda tongue-shaped. Dorsum pale with dark intersegmental sclerites. [On Gypsophila sp.; Grece. Fig. 5C] A. graeca sp. n. Antennal segment VI processus terminalis at most 1.1 times antennal segment III and at most 3.1 times antennal segment VI base. Longest dorsal setae on abdominal segment $2-4$ are $7-13 \mu \mathrm{m}$. Cauda triangular, sometimes slight constricted. Dorsum with variable sclerotisation and pigmentation, sometimes mostly pale. [On Silene sp., and an unidentified caryophyllaceous species; Iran. Fig. 5D] A. amphorosiphon sp. $\mathrm{n}$. Abdominal (or thoracic-abdominal) discal plate present, sometimes divided in transversal bands.

Abdominal discal plate absent; a broken an irregularly edged spinopleural patch usually present, sometimes with bridges to marginal sclerites 
$7 \quad$ Mesosternal processes wide and low. Longest dorsal setae on abdominal segment $2-4$ are $10-11 \mu \mathrm{m}$. Discal plate sometimes divided in transversal bands. Siphunculus 1.6-2.0 times cauda, which has 7-11 setae. [On Melandrium album; Kazakhstan. Kadyrbekov (2013): fig. 6]

A. melandrii

- $\quad$ Mesosternal processes more or less narrow and tall. Longest dorsal setae on abdominal segment $2-4$ are $10-55 \mu \mathrm{m}$. Discal plate always complete. Siphunculus 1.6-2.6 times cauda, which has 5-8 setae. [On Saponaria sp., Silene commutata, Si. kuschakewiczii, Si. lithophila, Si. vulgaris, Si. wallichiana, Si. wolgensis and Si. sp.; Kazakhstan, Pakistan, Tajikistan, and India. Fig. 1A] A. ornatella Siphunculus 1.7-2.7 times cauda. Longest frontal setae 22-28 $\mu \mathrm{m}$ and 1.01.4 times basal diameter of antennal segment III. [On Gypsophila altissima and G. paniculata; Kazakhstan. Kadyrbekov (2013): fig. 4].....A. naimanica Siphunculus 1.5-1.7 times cauda. Longest frontal setae 35-40 $\mu \mathrm{m}$ and 1.61.8 times basal diameter of antennal segment III. [On Cerastium cerastoides; Kazakhstan. Kadyrbekov (2013): fig. 5]

A. alatavica First segment of tarsi with 4 or less habitually with 3 setae. [Head and prothoracic transversal band as dark as thoracic-abdominal discal plate. Siphunculi cylindrical and straight. On Rosaceae species] First segment of tarsi habitually with 3 setae, sometimes with 2; very infrequently with 4

Antennal segment VI processus terminalis 2.2-2.7 times antennal segment VI base. Ultimate rostral segment with 2-5 accessory setae. Marginal tubercles usually present on abdominal segments 2-4. [On Prinsepia sinensis; Russia (Far Est, Primorsky Krai). Fig. 1D]

A. mordvilkoi

Antennal segment VI processus terminalis 3.8-4.2 times antennal segment VI base. Ultimate rostral segment with 8-10 accessory setae. Abdominal marginal tubercles always absent. [On Prunus erythrocarpa, P. fruticosa, $P$. incana, P. spinosa, P. tianschanica, P. triloba, P. ulmifolia, P. verrucosa and Prunus sp.; Georgia, Kazakhstan, Iran, Uzbekistan, Tajikistan, and Kyrgyzstan. Fig. 2A]

A. bozhkoae

11 Siphunculus slightly swollen with a maximal width close to 1.2 times minimal stem width and 1.6-2.0 times cauda, which is 1.5-1.8 times its basal width and has 7-11 setae; both as dark as head dorsum and thoracic and abdominal sclerotisation (a discal plate can be present). Longest dorsal setae on abdominal segment $2-4$ are $10-11 \mu \mathrm{m}$ and approximately 0.5 times basal diameter of antennal segment III. [On Melandrium album; Kazakhstan. Kadyrbekov (2013): fig. 6]

A. melandrii

- Characters not in above combination

12 Siphunculus at most 1.95 times cauda (which is short triangular), pale or uniformly dusky and slight swollen. Dorsum of head and mesosternal processes pale. Segmental thoracic and abdominal sclerotisation and pigmentation absent. 
- Siphunculus at least 1.90 times cauda, both diversely shaped and coloured. Dorsum of head and mesosternal processes pale or pigmented. Thoracic and abdominal segmental sclerotisation and pigmentation rare completely ab-

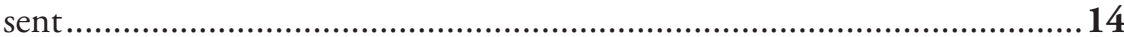

13 Siphunculus at least $0.26 \mathrm{~mm}, 0.6-0.95$ times antennal segment III, and 1.7-1.95 times cauda, which is longer than its basal width. Mesosternal processes conspicuous. [On Dianthus carthusianorum, D. caryophyllus, D. commutatus, D. monspessulanus, D. rupicola, D. sp. and Silene borysthenica, Portugal, Spain, France, Switzerland, Italy and Ukraine. Fig. 3A] Siphunculus shorter than $0.20 \mathrm{~mm}, 0.41-0.56$ times antennal segment III, and 1.7-1.9 times cauda, which is not longer than its basal width. Mesosternal processes sometimes inconspicuous. [On Dianthus sp.; Pakistan. Fig. $5 \mathrm{~B}]$

A. pakistanensis sp. n.

14 Antennal segment I at least 1.25 times its maximal width. Longest dorsal setae on abdominal segments $2-4$ are 35-55 $\mu \mathrm{m}$ and $1.5-2.0$ times basal diameter of antennal segment III. [Discal plate oval and dark. Siphunculi weakly ornamented, smooth distad. On Silene italica, S. nutans, perhaps $S$. viscosa, and S. sp.; France, Italy, Greece. Fig. 2B]

A. delmasi

- $\quad$ Antennal segment I at most 1.1 times its maximal width. Longest dorsal setae on abdominal segments $2-4$ at most $25 \mu \mathrm{m}$ and 1.2 times basal diameter of antennal segment III 15

15 Abdomen usually with spinopleural patch and separate marginal sclerites; if a discal plate is present then it has irregular margins and frequently there are windows in spinal areas of the thoracic, if integrated, and anterior abdominal segments. Dorsal patch or plate smooth and reticulated. Siphunculi dark brown to black, subcylindrical and usually straight, 1.8-2.0 times cauda, which is broad triangular and has 10-16 setae. Ultimate rostral segment with 6-10 accessory setae. [On Silene inaperta, S. italica, S. nutans, S. saxifraga, S. otites, S. vulgaris, S. wolgensis and S. sp.; France, Switzerland, Italy, Hungary, Romania, Ukraine and Russia. Fig. 2C].

A. ornata

- Characters not in above combination................................................... 16

16 Longest setae on abdominal segments 2-4 (dorsum) and antennal segment III 3-8 $\mu \mathrm{m}$ and $0.15-0.50$ times basal diameter of antennal segment III ....... 17

- $\quad$ Longest setae on abdominal segments 2-4 (dorsum) and antennal segment III $8-25 \mu \mathrm{m}$ and $0.15-0.50$ times basal diameter of antennal segment III; if they are $8 \mu \mathrm{m}$ long then marginal abdominal tubercles present or ultimate rostral segment shorter than second segment of hind tarsi. 18

17 Siphunculi dark brown, head dorsum, mesosternal processes and cauda brown to dark brown. Ultimate rostral segment 1.15-1.25 times second segment of hind tarsi. Cauda 1.4-1.8 times its basal width. [On Gypsophila paniculata, Silene borysthenica, S. moldavica, S. otites, S. wolgensis and S. sp.; Slovakia, Hungary, Greece, Ukraine, and Moldova. Fig. 2D] 
- $\quad$ Siphunculi (with smoked apex, head dorsum, mesosternal processes and cauda pale. Ultimate rostral segment as long as second segment of hind tarsi. Cauda 1.0-1.1 times its basal width. [On Gypsophila perfoliata; Kazakhstan. Kadyrbekov (2013): fig. 1]

A. togaica

18 Marginal tubercles on abdominal segments 2-4 and usually at least 1 spinal tubercle on abdominal segment VIII. [Cauda triangular 0.92-1.05 times its basal width. On Prunus. Iran. Fig. 6A] A. iranensis sp. $\mathbf{n}$.

- Marginal and spinal abdominal tubercles absent 19

19 Siphunculi pale, usually as pale as most part of tibiae................................20 Siphunculi pigmented, usually darker than most part of tibiae.

20 Antennal segment VI processus terminalis 5.0-5.5 times antennal segment VI base. Cauda triangular or tongue-shaped with slight proximal constriction. Ultimate rostral segment shorter than second segment of hind tarsi. [On Gypsophila arenaria, G. paniculata, G. perfoliata, G. sp.; Slovakia, Hungary, Ukraine, Kazakhstan, Russia (Western Siberia). Fig. 6C] A. gypsophilae Antennal segment VI processus terminalis 2.8-4.0 times antennal segment VI base. Cauda tongue-shaped. Ultimate rostral segment 1.23-1.45 times second segment of hind tarsi. [Clypeus swollen both forward and laterally. On Spergularia marina; Iran. Fig. 5D] A. urmiensis sp. $\mathrm{n}$.

21 Cauda tongue-shaped, 1.40-1.80 times its basal width. Mesosternal processes more or less pigmented, usually darker than tibiae. [Thoracic and abdominal sclerotisation variable, usually a spinopleural abdominal patch with irregular edges and windows in several segments, including the posterior ones. Siphunculi pigmented, but usually pale than abdominal sclerotised dorsum. On Dianthus barbatus, D. caryophyllus, D. crinitus, D. sp., Silene conoidea, S. fruticosa, S. italica, S. otites, S. paradoxa, S. thymifolia, S. vulgaris, and S. sp.. Spain, France, Italy, Slovenia, Hungary, Greece, Bulgaria, Turkey, Israel, Iran, Afghanistan, Pakistan, Tajikistan, and Russia (Asiatic part). Fig. 1C]

A. picta

- Cauda triangular, although sometimes with a slight proximal constriction, $1.05-1.40$ times its basal width. Siphunculi and mesosternal processes as pale as tibiae.

22 Ultimate rostral segment $0.90-1.00$ times second segment of hind tarsus, with $8-10$ accessory setae. Cauda approximately $1.30-1.40$ times its basal width. Longest dorsal setae on abdominal segment $2-3$ are $8-11 \mu \mathrm{m}$ and 0.3-0.5 basal diameter of antennal segment III. [On Silene lithophila; Kazakhstan. Kadyrbekov (2013): fig. 2]

A. massagetica

- Ultimate rostral segment 1.05-1.45 times second segment of hind tarsus, with 10-16 accessory setae. Cauda approximately $1.05-1.35$ times its basal width. Longest dorsal setae on abdominal segment $2-3$ are 13-23 $\mu \mathrm{m}$ and 0.6-1.0 basal diameter of antennal segment III. [On Silene gallica and $S$. paradoxa; France. Figs 4A, B] 
A. pujoli (from Blackman and Eastop op. cit.) and $A$. delmasi (this paper) are monoecious holocyclic, and $A$. amphorosiphon is very possibly holocyclic (this paper). The life cycle of the other species of the genus is unknown. It is possible that three types of life cycle currently exist in this genus, as in Brachycaudus van der Goot, 1913: (i) monoecious (and probably holocyclic) on a rosaceous species (e.g. A. bozhkoae on Prunus spp. and $A$. mordvilkoi on Prinsepia sinensis), (ii) monoecious on a caryophyllaceous species (and also probably holocyclic, e.g. A. delmasi and $A$. pujoli), and (iii) dioecious cycle with rosaceous species as primary host, and caryophyllaceous species as secondary host.

For us the more probable hypothesis is that all current species of Aphidura are monoecious, but that their common ancestor was dioecious, as in various other genera of Macrosiphini, and later the Aphidura branch diversified into two monoecious lineages, one Rosaceae-feeding and the other Caryophyllaceae-feeding. This is analogous to the South American species of Pentamyzus Hille Ris Lambers, 1966 which are all monoecious holocyclic, with several species living on Acaena (Rosaceae) and others on Alopecurus, Hordeum or Poa (Poaceae) (Nieto Nafría et al. 2002).

\section{Acknowledgments}

Authors wish to thank the Muséum national d'Historie naturelle of Paris (France) for the facilities given for the study of the Aphidura slides of its collection. They acknowledge Dr. Roger Blackman for the critical reading of the manuscript draft, and for several pieces of information about the specimens conserved in the Natural History Museum in London. Also our thanks to Andrey V. Stekolshchikov (Zoological Institute, Russian Academy of Sciences, St. Petersburg) who provided us with the translation of the Kadyrbekov's recently published paper, and to L. M. Fernández Blanco for taking photomicrographs and preparing figure plates.

\section{References}

Andreev AV (2004) The subgeneric classification of Brachycaudus van der Goot. In Simon JC, Dedryver CA, Rispe C, Hullé M (Eds) Aphids in a new milenium. INRA Editions. Versailles, France, 111-117.

Blackman RL, Eastop VF (1994) Aphids on the World's Trees. CAB International, Wallingford, United Kingdom, 8+1004 pp. Actualized 2013: Aphids on the World's plants. An online identification and informative guide. http://www.aphidsonworldsplants.info [accessed April 2013]

Blackman RL, Eastop VF (2006) Aphids on the World's herbaceous plants and shrubs. Volume 1 Host Lists. Volume 2 The Aphids. John Wiley and Sons Ltd. Chichester, United Kingdom, 8+1439 pp. Actualized 2013: Aphids on the World's plants. An online identification and informative guide. http://www.aphidsonworldsplants.info [accessed April 2013] 
David SK, Sekhon SS, Bindra OS (1970) New aphids from North-West India (Homoptera: Aphididae). Bulletin of Entomology 11 (2): 150-155.

Eastop VF, Blackman RL (2005) Some new synonyms in Aphididae (Hemiptera Sternorrhyncha). Zootaxa 1089: 1-36.

Gómez-Menor Ortega J (1950) Algunas especies nuevas de áfidos (Homoptera, Aphidae). Eos extraordinario 1950: 97-118, $5 \mathrm{pl}$.

Hille Ris Lambers D (1956) Two new genera of Aphididae (Homoptera). Bolletino del Laboratorio di Entomologia Agraria «Filippo Silvestri» di Portici, 14: 292-197.

Holman J (2009) Host Plant Catalog of Aphids. Palaearctic Region. Springer, Germany, 1216pp. doi: 10.1007/978-1-4020-8286-3

Kadyrbekov RK (2013) Materiali po sistematike tlei roda Aphidura Hille Ris Lambers, 1956 (Homoptera, Aphididae). Zoologicheskii Zhurnal 92 (1): 34-49. doi: 10.7868/ S0044513413010078

Mamontova-Solukha VA (1963) Novie dani pro faunu popelits' (Homoptera. Aphidoidea) Ukrainyi. Pratsi Institutu Zoologii Akademii Nauk Ukraiskoyi RSR 19: 11-40, 7 pl.

Mamontova-Solukha VA (1968) Novye vidy tley (Homoptera, Aphidinea) iz stepey Ukrany. Vestnik Zoologii 2: 33-45.

Narzikulov MN (1958) Novye dlya nauki tli (Homptera: Aphididae) iz Tadzikistana. Trudy Akademii Nauk Tadzikistana SSR 89: 15-30.

Narzikulov MN, Winkler NG (1960) Novye vidy roda Aphidura H.R.L. (Homoptera, Aphididae) iz Tadzikistana. Doklady Akademii Nauk Tadzikistana SSR 3 (5): 49-54.

Naumann-Etienne K, Remaudière G (1995) A commented preliminary checklist of the aphids (Homoptera: Aphididae) of Pakistan and their host plants. Parasitica 51 (1): 1-61

Nieto Nafría JM, Andreev AV, Binazzi A, Mier Durante MP, Pérez Hidalgo N, Rakauskas R, Stekoshchikov AV (2012) Hemiptera: Aphidoidea. In de Jong, YSDM (Ed.) Fauna Europaea version 2.5. http://www.faunaeur.org [accessed April 2013]

Nieto Nafría JM, Mier Durante MP (1998) Hemiptera Aphididae I. In Ramos MA et al. (Eds) Fauna Ibérica, vol. 11. Museo Nacional de Ciencias Naturales (CSIC). Madrid, Spain. 424 pp.

Nieto Nafría JM, Mier Durante MP, Ortego J (2002) Pentamyzus Hille Ris Lambers, a Neotropical genus of the tribe Macrosiphini (Hemiptera: Aphididae: Aphidinae) with the description of a new species. Proceedings of the Entomological Society of Washington 104: 918-927.

Pashchenko NF (1968). Aphidinea. In Lehr A (Ed) Keys to the Insects of the Far-East of the USSR. Volume II. Homoptera and Hemiptera: 1-149. [English version of a Russian original] Nauka Publishing House. Leningrad (USSR).

Pintera A (1970). A new species of the genus Aphidura Hille Ris Lambers (Homoptera, Aphidoidea) from Bulgaria. Acta Entomologica Bohemoslovaca 67: 241-244.

Remaudière G (1989) Quatre Aphinae nouveaux de l'Iran [Homoptera, Aphididae]. Revue Française d'Entomologie (Nouvelle Série) 11: 175-187.

Remaudière G, Leclant F (1965) Un Aphidura nouveau du Sud de l'Europe (Hom. Aphididae). Annales de la Société Entomologique de France (Nouvelle Série) 1 (3): 717-722.

Shaposhnikov GC (1950) Sistematicheskie otnoshenja mezdu rodami tlej v podtribe Anuraphidea. Entomologicheskoe Obozrenie 31 (1-2): 213-228. 
Shaposhnikov GC (1984) Podotryad tli - Aphidinea. In Kopaneva ML (Ed), Opredelitel' vrednykh i poleznykh nasekomykh i kleshchey plodovykh i yagodnykh kul'tur v SSSR Kolos, Leningrad, URSS, 59-73.

Szelegiewicz H (1967) Neue Blattlaus-Arten (Homoptera: Aphididae) aus Ungarn. Acta Zoologica Academiae Scientarum Hungaricae 13 (3-4): 433-444. 